\title{
From building to architecture: The rise of configurational thinking in Bronze Age Crete'
}

\begin{abstract}
This paper is based on the identification - through space syntax analysis of Neopalatial architecture (Late Bronze Age Crete, C. I600-I425 BC) - of a large number of topological and quantitative recurrences within the Minoan architectural landscape. These findings allow us to recognize a genotype (i.e. an underlying set of principles) that permeated the Minoan built environment, forming a continuum between domestic buildings (houses) and monumental and communal structures (such as the so-called 'palaces'). Using the Neopalatial genotype as a starting point and extending the space syntax analysis to earlier built forms, this paper aims at investigating the development of Minoan architectural language. This research establishes that, at the end of the Middle Minoan Period if not earlier - a seemingly conscious concern about structure, i.e. spatial configuration, manifested itself, contributing to a shift from vernacular building to 'theoretical' architecture. Bearing that in mind, this paper intends to further investigate processes of invention, innovation and diffusion across different scales within Minoan architectural tradition.
\end{abstract}

\section{Introduction}

The Neopalatial period (ca. I600-I425 BC), often considered the golden age of Minoan civilization, witnessed the development of an elaborate architectural repertoire that spread throughout the island and had repercussions many miles away from its shores (Driessen I989-I990; Shaw 2009). This 'Neopalatial Style' is characterized by the extensive use of specific architectural features, including timber construction, ashlar walls, cut stone door jambs, pier-and-door partitions, etc. Simultaneously, certain room types - and in particular the so-called 'lustral basins' and 'Minoan halls' - were widely represented in buildings of various size and architectural elaboration. Some of these features preexisted, others were new, but their large-scale distribution is what really sets this 'Neopalatial Style' apart: they occur all over Crete first, in the Cyclades and on the Greek mainland afterwards.

Although it would be a mistake not to consider these formal properties as an integral part of Neopalatial architecture, it would be even more misleading to take them as its essential constituents. Neopalatial architectural language definitely had a vocabulary of its own, but what truly distinguishes it are its grammatical rules. In earlier work I attempted to high-

I This paper was originally presented at the $6^{\text {th }}$ annual conference of the European Association of Archaeologists (I-5 September 20I0, The Hague) in a session dedicated to space syntax. These researches were made possible thanks to the support of the Fonds National de la Recherche Scientifique (F.R.S.-FNRS). I am very much indebted to Charlotte Langohr, Jan Driessen and Simon Jusseret for their constructive critiques, comments and suggestions. 
light the configurational properties of Neopalatial architecture, ${ }^{2}$ and space syntax provided the theoretical framework and tools to achieve this goal (cf. Hillier, this volume). Building on pioneer work by Preziosi and Palyvou on formal and circulatory patterns in Minoan architecture (Preziosi i983; Palyvou I987), some 70 buildings were analysed, from modest houses to monumental 'palaces' (Letesson 2009).

Despite the great formal diversity of the corpus, all the buildings share common structural properties. Some were elementary, such as the strong demarcation between the exterior world and the internal domain of a building, others were much more elaborate, including the integration inequality genotype of the so-called 'palaces' (see below). Furthermore, it is necessary to underline that, to some extent, Neopalatial architecture shows strong formal links with Prepalatial and Protopalatial building traditions, while structurally it appears extremely innovative. Consequently, several new spatial patterns clearly depart from more traditional ways of organizing space. I will come back to some of these issues, but first I will briefly address the concept of vernacular architecture.

\section{Vernacular architecture}

Traditionally, in architectural studies, the vernacular character is considered to be the exact opposite of polite, or "High Style" architecture. It is stated that "polite architecture [...] is typically designed and built by professionals following national or international styles, often using exotic materials and adventurous techniques to achieve aesthetically pleasing results. It undergoes significant change through time, and is most often studied chronologically. Vernacular architecture, on the other hand, is generally built by amateurs, often the people who will use it, guided by local conventions, using locally available materials and traditional techniques. Basically conservative, it changes relatively little through time, but lends itself to study by region.”(McEnroe I990, p. I95).

Even if studies of vernacular architecture represent a non-negligible contribution to the discussion of the built environment, the very use of the term 'vernacular' has rightly been criticized in recent years. Blier pointed out: "vernacular, like other building taxonomies, reveals as much about modern (largely Western) classification values as about the salient issues addressed by the structures themselves. Among other things, the prominence of binary oppositions posited vis-à-vis 'vernacular' versus 'polite' architecture [...] reveals the enduring nature of Western dualistic thinking." (Blier 2008, p. 23I).

Starting with Forde's major book, Habitat, Economy, and Society (Forde I934), and reinforced by an ever-increasing number of case studies and theoretical debates, the idea that buildings, whatever their level of complexity, are shaped fundamentally by human deci-

2 In space syntax, 'configuration' refers to a set of interdependent relations in which each is determined by its relation to all the others (Hillier I996, p. 35; cf. also Hillier, this volume). 
sions is now well anchored. This contributed to downplaying - without negating - issues of shelter, as well as contextual factors like climate, topography and available materials as the most salient determinants of building form (Glassie 2000, p. 9I-94).

In a similar vein, Glassie raised an interesting question: "If every building is a cultural fact, the consequence of a collision between intentions and conditions, if differences of culture and circumstances adequately account for differences among buildings, the question is why we persist in calling some of them vernacular" (Glassie 2000, p. 20). In his view, calling buildings 'vernacular' is a way of highlighting their cultural and contingent nature, so that the term 'vernacular' is one of the tools that can be used when we wish to crack architectural objects open and learn their meanings (Glassie 2000, p. 2I). Glassie also noted that what makes vernacular architecture is first and foremost the cultural congruity in design, construction and use (Glassie 2000, p. 46). This specific understanding of the concept is essential in itself and central to the present argument. It also finds a stimulating echo in the difference between building and architecture underlined by Hillier in Space is the Machine (Hillier I996).

\section{Building vs. architecture}

In its theoretical preliminaries, the book opens with the question "what architecture adds to building" (Hillier 1996, p. I5-53). Focusing on what buildings - and more generally built environments - are, Hillier elaborates on how they take part in the 'transmission of culture through artefacts' (Hillier 1996, p. 42-43, n. 20). At the centre of the argument lies the concept of the non-discursivity of configuration, 3 the fact that in all areas where we use rule systems to behave in ways which are recognizable as social, some hidden structures we think with (i.e. unconscious configurational rules) seem to prevail. This corresponds to 'social knowledge', the purpose of which is "to create, order and make intelligible the spatio-temporal events through which we recognize the presence of culture in everyday life." (Hillier I996, p. 40). This type of knowledge is normative in the sense that it creates society through habits of doing and practices hiding the abstract principles that bring spatio-temporal phenomena together into meaningful patterns. Social knowledge is about how to behave in the world, but there is also knowledge that seeks to understand the world, that is to say analytic or scientific knowledge. In social knowledge we unconsciously follow the underlying rules and therefore behave appropriately; in analytic knowledge we bring these abstract structures into our awareness to examine them critically and, if necessary, to reconstitute them (Hillier 1996, p. 4I).

3 'Non-discursive' in the sense that we do not know how to talk about it (Hillier I996, p. 38; cf. also Hillier, this volume). 
Social knowledge plays a decisive role in the shaping of built space. Spatial and formal patterns that are created through buildings and settlements often correspond to intricate codes that govern, for example, which types of space there are, the way they are connected and sequenced, what activities take place together in them and which ones have to be separated, what categories of persons have access to them and their respective rights, how they are decorated and furnished, what types of objects are expected in them, and so on. These patterns vary from one cultural group to the other, but usually members of the group handle these spatial codes without thinking of them and even without being aware of them until they are challenged or until they are confronted to another form of patterning in another culture (Hillier 1996, p. 43). It is by means of this significant underpinning by nondiscursive configurationality that buildings become parts of the transmission of culture through artefacts'. For example, we can think consciously of a prison as a physical object and have a mental image of it and we can think of its parts as physical or spatial parts, like cells, entrance gate or exercise yard. But if we think of a prison as a whole entity it will be through the unconscious intermediary of configuration, in the sense that "when we think of a particular kind of building, we are not only conscious of an image of an object, but at the same time of the complex of spatial relations that such a building entails" (Hillier I996, p. 43). In the case of the prison, this complex of spatial relations is related to the coexistence, within the same compound, of radically different categories of users (inmates, wardens and visitors) requiring radically different modes of movement and occupation.

Thus it appears that it is essentially through unconscious principles and codes that the raw materials of space and form are given social meanings in the built environment. Nevertheless, it is not because buildings are instances of the transmission of culture through artefacts that buildings of the same type and culture will be identical to each other. As was already mentioned, Neopalatial Cretan architecture, like many other examples of vernacular architecture, is a combination of an underlying common structure (i.e. a genotype) and a surface variety or heterogeneity of physical expressions (i.e. the phenotypes). This is because vernacular builders use rule sets that are tacit and taken for granted, ideas they think with rather than of. 4 These ideas "specify not the specific but the generic, so that vernacular designer may use the rules as the basis of a certain restrained creativity in interpreting the rules in novel ways" (Hillier 1996, p. 45). This accounts for the diversity within the architectural corpus of a given culture. On the other hand, the house built by a builder sharing the culture of a community comes out right because it draws on the normative rules of a shared social knowledge. In that case, there is, as Glassie pointed out, cultural congruity in design, construction, and use.

If the act of building is intimately related to the unconscious reproduction of abstract principles and culturally sanctioned codes and their materialization in the spatial and physical forms of the built environment, architecture must be something more. According

4 This corresponds to Henry Glassie's 'architectural competence' (Hillier I996, p. 44). 
to Hillier, there is architecture when "the configurational aspects of form and space, through which buildings become cultural and social objects, are treated not as unconscious rules to be followed, but are raised to the level of conscious, comparative thought, and in this way made part of the object of creative attention" (Hillier i996, p. 45-46). Therefore, architecture happens when there is a shift from social knowledge to analytic or theoretical knowledge during the creation of a built form. It means that, at some point during the creative process, an intellectual choice amongst the range of possibilities takes place and leads to a successful accomplishment that goes beyond cultural reproduction. Therefore, the reflective thought generates invention or at least innovation at the level of the underlying structure of the built form. In summary, the preconditions for architecture are: I) analytical knowledge in action and 2) invention at the level of the genotype.

It thus goes without saying that architecture does not necessarily depend on architects but can exist within the context of what we would normally call the vernacular. This does not mean that the innovative production of buildings which are phenotypically individual within the vernacular should be thought of as architecture (Hillier i996, p. 47). Indeed, as mentioned, phenotypical heterogeneity is the normal product of the unconscious materialization of culturally constrained codes. The designer of a building truly turns it into architecture when he or she takes into consideration possibilities that are not contained in contemporary cultural knowledge but which are at the same time within the field of what is architecturally possible.

This is, I believe, exactly what happened at the beginning of the Late Bronze Age in Crete or perhaps, as we shall see, even earlier, at some point during the Middle Bronze Age. Nevertheless, even if we acknowledge this difference between building and architecture, there is no clear-cut limit to be drawn. Either can become the other at any moment. Broadly speaking, in the evolution of building, there are two ways in which things are done: in obedience to a tradition, or in pursuit of innovation. "Building contains architecture to the degree that there is non-discursive invention, and architecture becomes building to the degree that there is not. Vernacular innovation is therefore included within architecture, but the reduplication of vernacular forms is not. Architecture is therefore not simply what is done but how it is done" (Hillier I996, p. 49). ${ }^{5}$ Indeed, the boundary between the vernacular and architecture is constantly shifting. Usually, it is concomitant to the greatest changes that reflective thought transcends vernacular tradition and leads to architectural invention ${ }^{6}$ which, eventually, will be the cornerstone of a new vernacular language.

5 "The bringing of the non-discursive, configuration dimension of built form from cultural reproduction to reflective awareness and abstract exploration of possibility is at once a passage from the normative to the analytic and from the cultural bound to the universal, the latter meaning that all possibilities are open rather than simply the permutations and phenotypical innovations that are sanctioned by the vernacular." (Hillier I996, p. 49).

6 On this concept of invention being related to contextual changes, see also van der Leeuw: "Once certain solutions have been found, the sheer complexity of the network and of the instantiation procedures favours the con- 
It is also worth noting that, in vernacular tradition, form, spatial and functional patterns are known in advance and only need to be recreated, but architecture, because of its very nature, uncouples these features of the building from their reliance on social knowledge. Therefore, the form-function relationship - and above all its social outcomes becomes uncertain. Recently, this idea was explored in the context of the new spatial patterning of the Neopalatial period and its potential social consequences (Letesson and Driessen 2008).

\section{Invention, innovation, and tradition}

The foregoing discussion about what architecture really is raised the question of the relation between tradition and innovation, but it still requires more thorough consideration. First of all, there is a difference between invention and innovation. In a paper devoted to understanding the concepts of invention and innovation through network analysis, van der Leeuw defined the former as a local process: "Only those agents that are immediately connected to the inventor(s) are involved and the process is therefore one that plays out in a relatively limited number of dimensions comprising the immediate articulation of the know-how of the inventor(s) with the other agents in their material world" (van der Leeuw 2008, p. 242). Usually, innovation takes place on a different scale. It is the process by which an invention is adopted and spreads throughout a population. Therefore, it involves a much larger network of agents (van der Leeuw 2008, p. 225 and 242-243). Van der Leeuw's core argument is that, by understanding the structure and the dynamics of the complete network (objects and things, human and non-human agents) involved in the processes of invention and innovation, it is possible to grasp and conceive them properly (van der Leeuw 2008, p. 229-230). Furthermore, according to Roux, invention is more of a cognitive phenomenon, whereas innovation is better considered a historical phenomenon (Roux 20I0). Inventors are skilled individuals whose expertise and cognitive abilities allow them to develop exploratory behaviour. Therefore, by going beyond the cultural representations associated with their ways of doing things, they are able to 'force' the technical system and its associated identity (Roux 20I0). She also underlined the fact that in the process of innovation, what is chosen is usually the context of production rather than the technique itself (Roux 2010).

Returning to Hillier's distinction between building and architecture, it can be said that architecture happens when there is invention at the level of the genotype. This usually leads to innovation, that is to say, the diffusion and adoption of the new principles on a larger scale. Eventually, this innovation process - being widely distributed, digested and culturally sanctioned - establishes the foundations of a new vernacular tradition. As was mentioned

tinued use of these 'solutions' over the invention of new ones as long as the context is the same" (van der Leeuw 2008, p. 236). 
above, it is therefore quite tricky to draw a precise line between architectural invention, consecutive innovation and the emergence of a new vernacular tradition. A real understanding of these processes requires a detailed analysis of all the agents involved - human or nonhuman - and an assessment of their complex relational patterns. This paper is a first attempt to lay solid bases for further investigation of the development of the Minoan built environment. Our starting point revolves around the understanding of the emergence of the 'Neopalatial Style' and of its proliferation.

\section{Neopalatial architectural genotype}

At the beginning of the gos, Driessen was the first to comment on the emergence of a new architectural language in the Neopalatial period and its proliferation throughout the island of Crete (Driessen I989-I990). At the time, the so-called 'palaces' were seen as the probable birthplace of these innovations (pier-and-door partitions, lustral basins, Minoan halls, masons' marks, real ashlar masonry, etc.), which is why the term 'palatial style' was coined to identify this assemblage.7 His study mainly focused on the new built forms and architectural features, realizing at the same time that something more essential was at stake at a deeper, structural level, especially when comparing Pre- and Protopalatial buildings with Neopalatial ones (Driessen I989-I990, p. 8).

The same year, McEnroe published a paper about the significance of local styles in Minoan vernacular architecture (McEnroe I990). Without denying the existence of the Neopalatial style and its proliferation, it offered a very interesting perspective on local expressions of an overall tradition. This paper contributed to including a focus on local factors (available materials, topography, etc.) and expertise in the debate about the Neopalatial style. From the gos onwards, in a very elementary form, the idea of various phenotypic expressions of an underlying genotype was already in the air. In Minoan studies, this concept was first promoted in I983 by Preziosi in his seminal book Minoan Architectural Design (Preziosi I983). ${ }^{8}$ Adopting a semiotic approach to built form, he was the first to go behind the lexicon of Minoan architecture in search of its underlying spatial logic: "[...] what distinguishes this architectural corpus are the patterns of association and relationship which it manifests, rather than a material homogeneity of formation." (Preziosi i983, p. 200).9 Even

7 Recently, this interpretation has been rightly challenged (Schoep 2002; 2004; 2006; 2010), see below.

8 Most of the ideas developed in this book were first explored in Preziosi's first book: The Semiotics of the Built Environment: an Introduction to Architectonic Analyses, I979.

9 "Possibly one of the most important discoveries in connection with the study of Minoan architecture has been the fact that (A) all of the cellular configurations found in the corpus can be seen as simple variants of a small set of basic conformations and proportions, and that (B) this limited set of forms reveals an internally coherent orderliness: the set of forms, in other words, comprises a system in its own right, in opposition to systems of other corpora" (Preziosi i983, p. 200). 
if his book did not get the reception that it deserved, a whole generation of scholars interested in Minoan architecture was directly or indirectly influenced by his writings. ${ }^{10}$

Furthermore, starting with Graham, the use of a systematic measuring unit and the existence of complex and well thought-out planning processes were studied and highlighted in Minoan architectural studies (Graham ig60; Cherry I983; Preziosi I983, p. 319-478 and 48I-482; Schmid I985; Hitchcock 1997; Preziosi 2003; Bianco 2003). ${ }^{\text {II }}$ The design of Minoan built forms - or of some of their parts - was also closely related to topographical or celestial features (Shaw I973; Preziosi I983, p. 50I-508; Driessen and Sakellarakis 1997, p. 72-73; Goodison 200I; Goodison 2004; Letesson and Vansteenhuyse 2006). Broadly speaking, there is general agreement about the existence of a high degree of elaboration within Minoan architecture, especially where the Neopalatial period is concerned.

The main goal of the research that constituted the basis of the present argument was twofold: a concern about overcoming the traditional focus on prestige architecture by integrating buildings of various size and elaboration within the corpus under study and an attempt to understand the underlying logic structuring its formal heterogeneity. Space syntax, by transforming every building - whatever its size - into a set of comparable data (i.e. j-graphs, visual maps and numerical values) ${ }^{\mathrm{I2}}$ in which relational patterns amongst spaces are the essential factor, offered the perfect analytical methodology and theoretical framework. ${ }^{13}$ Using space syntax to study Cretan Neopalatial architecture permitted the emphasis of a large number of topological and quantitative recurrences. These features are so often repeated between Minoan buildings that they allow the recognition of a genotype an underlying set of principles - that permeate the Minoan built environment and form a continuum between houses and 'palaces' (Letesson 2009).

Among the numerous properties of this Neopalatial genotype (Letesson 2009, p. 32I-368), only two are dealt with in this paper, since they reflect a drastic change from the earlier situation. There is indeed a stronger concern about the creation of a clear demarcation between inside and outside and a shift from an agglutinative mode to an articulated mode of organizing space (fig.I).

The former manifests itself in many ways, but the massive use of external transition spaces (vestibules, corridors, porticoes) is definitely its better crystallization. This suggests

I0 Driessen 1989-1990; McEnroe I990; Palyvou I987; Sanders 1988; Hitchcock 2000.

II The principle of a basic measuring unit is widely accepted, but its exact value is controversial, to say the least. I2 In the following figures the visual integration plan (in its $\mathrm{HH}$ version) was made on Depthmap (with a color scale ranging from red - high visual integration - to blue - low visual integration, cf. Turner 200I; 2004). Numerical values (such as RRA, control value, difference factor, and indexes of distributivity and asymmetry) as well as other visual maps (step depth, control, and controllability) associated with over 70 Neopalatial buildings can be found in Letesson 2009, p. 376-466.

I3 This paper does not present an in-depth assessment of this theoretical and methodological framework. The reader can nonetheless find a detailed overview here (Hillier, this volume; cf. also Letesson 2009, p. 5-18; Ostwald 20II); for a critical examination, cf. also Hacıgüzeller and Thaler, this volume. 
a
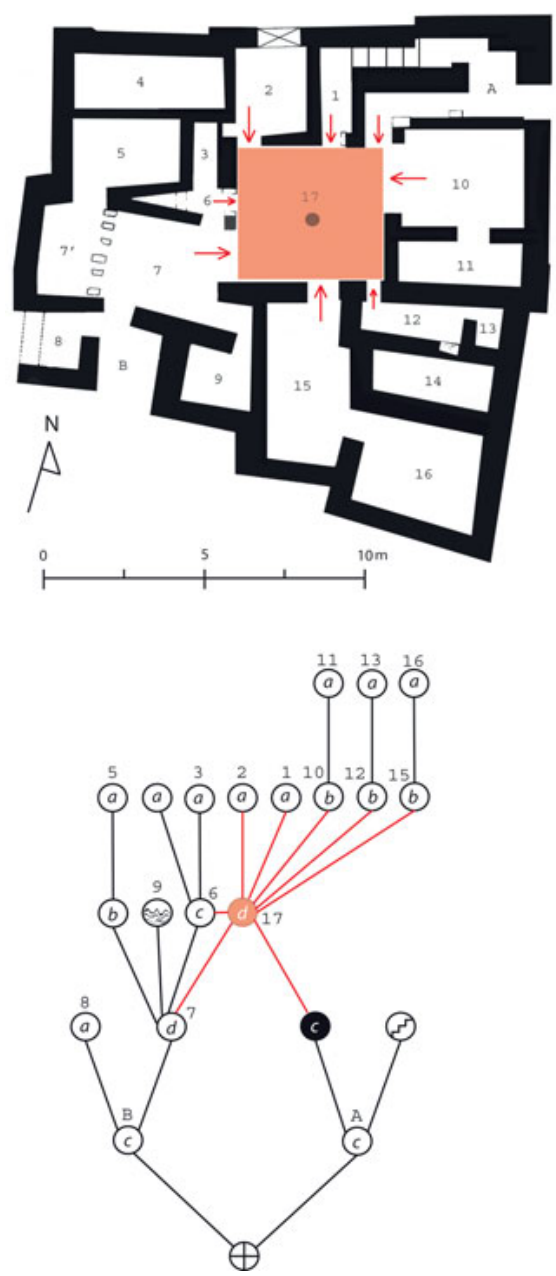

b
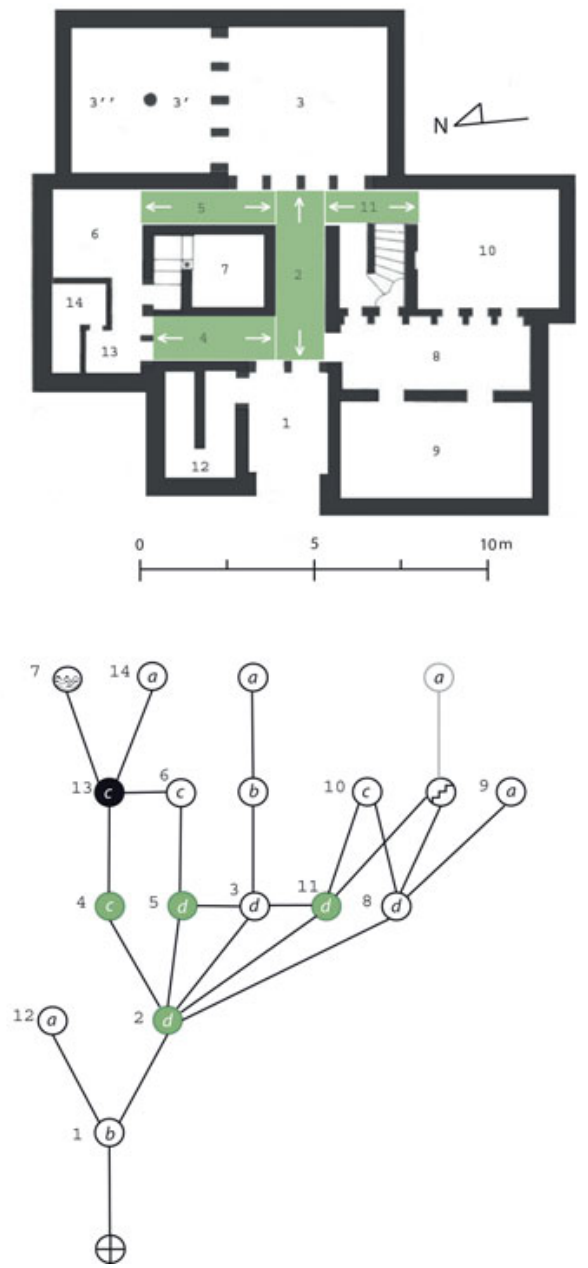

Figure 1 | Houses Zeta-Beta (a) and Delta-Alpha (b) - Malia - Survival of the agglutinative mode (a) VS proper articulated mode (b).

a growing concern about undesirable intrusions. ${ }^{14}$ It not only implies an attempt to reduce the permeability of a building, but also acts as an efficient signal, a way of underlining the shift from the external world to the internal domain. The very existence of such

I4 This may be linked to a space syntax concept called 'transpatial solidarity'. Hillier and Hanson I984, p. I45: “A solidarity will be transpatial to the extent that it [...] emphasizes the discreteness of the interior by strong control of the boundary. [...] The essence of a transpatial solidarity lies in the local reproduction of a structure recognizably identical to that of other members of the group. Such a solidarity requires the segregating effect of the boundary to preserve interior structure from uncontrolled incursion. Solidarity means in this case the reproduction of an identical pattern by individuals who remain spatially separated from each other, as well as from the surrounding world." 
external transition spaces emphasizes the fact that the contacts between the inside and outside of Neopalatial buildings were potentially so frequent and/or necessary that they needed to be strictly monitored. Indeed, they suggest frequent, planned encounters that formed integral parts of the social dynamics, tightly controlled and channelled through space. Pre- and Protopalatial structures mostly lack such spaces because encounters within them were probably between residents only (Sanders I990). ${ }^{15}$ When we add to this the fact that Neopalatial buildings often had more than one entrance and most of them were in fact either preceded or followed by external spaces of transition, the indications that different categories of visitors frequented the interior of structures become even more persuasive.

In Pre- and Protopalatial periods, houses mostly follow an agglutinative configuration, whereas in Neopalatial Crete the massive introduction of internal spaces of transition created articulated plans that categorized people and their activities more strictly and efficiently. The articulation therefore resulted in a spatial segmentation which is often considered to be concomitant with socio-political complexity, related to age, gender, status or other differentiations (Kent I990). Generally, this articulated mode of organizing space revolves around a particular space, the integration and visual controllability of which are extremely high, if not the highest, within the building (room 5 in fig. 2 b). These spaces were labelled 'poles of convergence' (Letesson 2009, p. 350), partly because most of the trajectories that crisscross a building had to pass through them. ${ }^{16}$ This probably implies that they were rooms to which people (or a selection of specific people) had equal access and equal rights. They were spaces fit for local interactions depending on spatial proximity, activities occurring at the same place by a gathering of people in space, such as a communal meal, a particular ritual performance, or hosting visitors. In Minoan studies, such 'poles of convergence' have usually been labelled as hosting/reception zones or more simply as the 'functional centre' of a building. Very frequently the particular function of such spaces is difficult to assess, and it is quite possible that they were essentially multi-functional, notably because everybody could relatively easily gain access to them (see for example Shaw and Shaw I996, p. 366-367). From a syntactical point of view, their essential feature is that they formed the main internal arena for encounters and co-presence in Neopalatial architecture. ${ }^{17}$ This becomes the more evident when comparing them with other spaces that were

I5 'Residents' are those whose identity as individuals is embedded in the spatial layout of a building and who therefore have some degree of control of space and privileged access to it. 'Visitors', on the other hand, are those who lack control over a particular building. Their access to space is usually temporary, subordinated to the control by the residents, with their social identity generally manifesting itself collectively (Hillier I996, p. 25I; cf. also Hillier and Hanson i984, p. I47).

I6 In a ringy j-graph, a 'pole of convergence' is a cell which is in a dominant position on a ring or through which several rings pass. In a tree-like configuration, a 'pole of convergence' is generally formed by a symmetrical disposition of cells subordinated to a pivotal space (Letesson 2009 , p. 350 ).

I7 The 'poles of convergence' illustrate perfectly the concept of 'spatial solidarity'. Hillier and Hanson I984, p. I45: “[...] a spatial solidarity [...] builds links with other members of the group not by analogy or isolation - as 

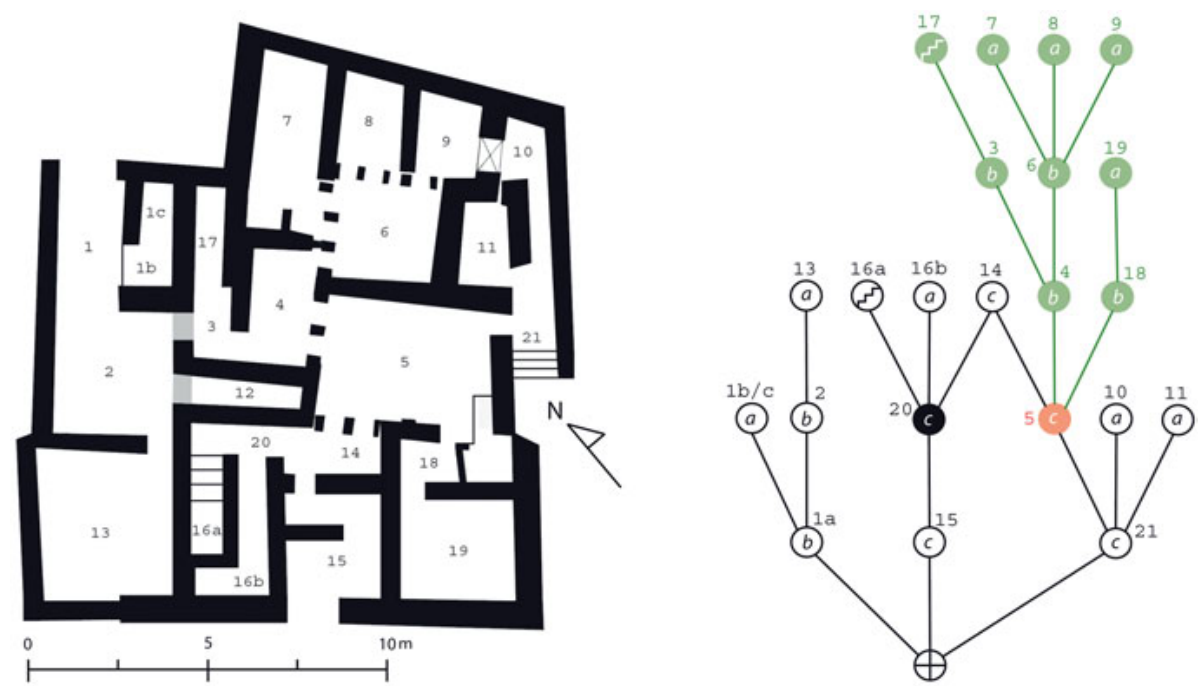

a

b

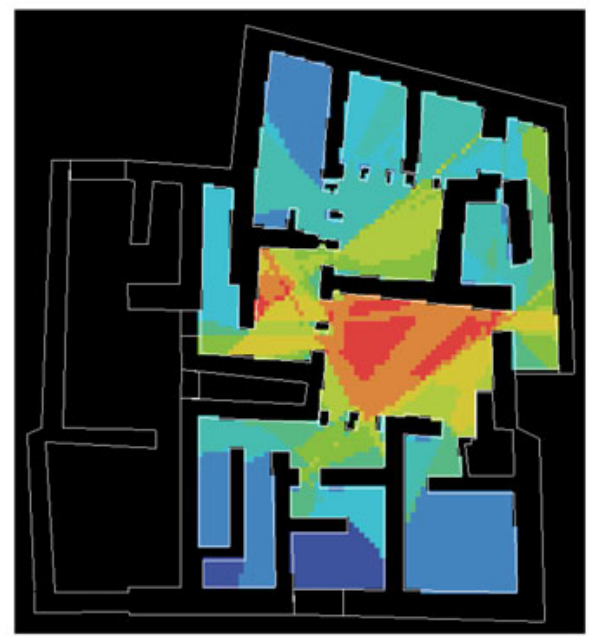

C

Figure 2 | Building 5 - Palaikastro - Plan (a), j-graph (b) and visual integration (c).

not accessible for all the members of the residential group and obviously even less for potential visitors, or with spaces that were more closely associated with particular activities to the exclusion of others, such as storerooms, workshops, etc. In terms of space syntax analysis, the latter usually develop in tree-like and linear arrangements (rooms 3, 4, 6-9,

transpatial solidarity does - but by contiguity and encounter. [...] Encounters have to be generated, not limited, and this implies the weakening of restrictions at and within the boundary. A spatial solidarity would be undermined, not strengthened, by isolation". 
and I7-I9 in fig. 2b), a type of spatial configuration which easily frames, distinguishes and articulates circulations and categories of people and activities in patterns of avoidance or controlled encounter.

This articulated mode of organizing space found its best expression in the configuration of the so-called 'palaces': multiple external transition spaces forming several external rings culminating in the central court, the pole of convergence par excellence (fig. 3 ). ${ }^{18}$ Beyond the central court, the spaces essentially formed tree-like linear sequences. In space syntax, ringy systems are often associated with encounters between residents or between residents and visitors, whereas tree-like sequences tend to categorize, articulate and frame people (mainly residents) and their respective behaviour, i.e. private, gender-related or
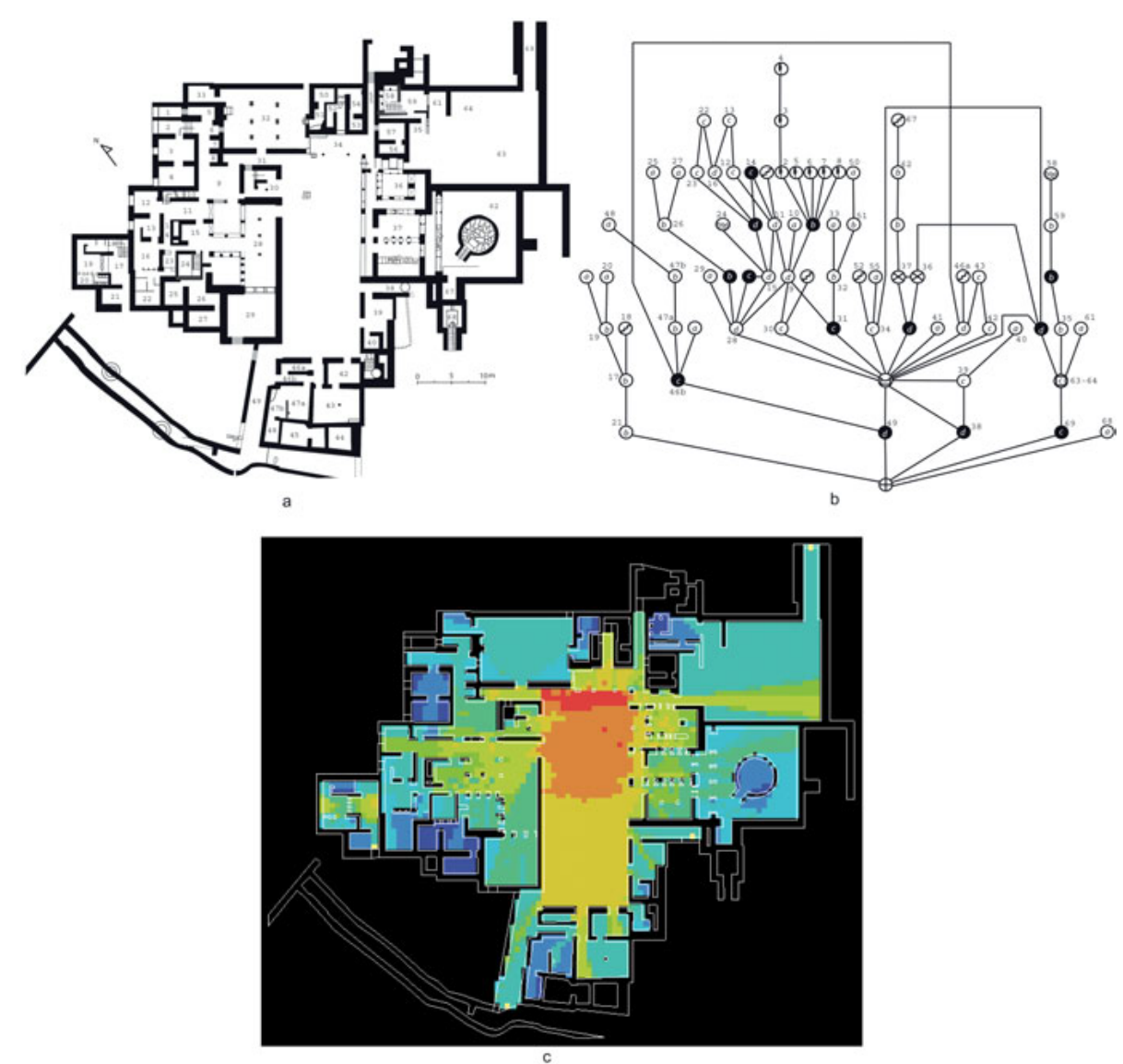

Figure 3 | 'Palace' - Zakros (2 ${ }^{\text {nd }}$ phase $)$ - Plan (a), j-graph (b) and visual integration (c).

I8 Here it is worth noting that, in terms of synchrony (Hillier I996, p. 232-233; Letesson 2009, p. 351), the investment of so much space in an open air cell is most certainly of great importance (cf. for example Letesson and Driessen 2008; Palyvou 2002). 
specialized activities (Hillier and Hanson I984, p. I66-I67). What is also surprising is that in all 'palaces' - as in several domestic structures - similar spaces show similar degrees of spatial connections (i.e. of integration value). There is in fact a hierarchical order, an integration inequality genotype (Hillier I996, p. 36-37 and 249; cf. also Hillier, this volume), starting with the Central Court - as the space with most connections - via the Minoan hall and different types of storage spaces to finally the lustral basins - as the most segregated space with only a single connection. It is because of this panel of recurrences that the "palaces' can be regarded as strong programme buildings (Hillier I996, p. 250-255; Letesson 2009, p. 354-355), that is to say buildings "in which it is not the layout that generates the movement pattern but the programme operating within the layout [...]: its aim is to reinforce certain categoric identities and create strongly controlled interfaces between them" (Hillier I996, p. 252).

\section{The rise of configurational thinking?}

Despite the fact that we know a lot more about Neopalatial architecture than about built forms in Pre-, Proto- or Postpalatial Crete, it is nonetheless clear that the former shows some radically different properties at the level of the genotype. These were properties that, added to new architectural features evoked earlier on, contributed to distinguishing the Neopalatial built environment from what existed before and after. ${ }^{19}$ Either before or just at the dawn of the Late Bronze Age, invention took place at the level of the genotype, transcending the culturally sanctioned built form and giving birth to architecture per se.

Nevertheless, the overall adoption of these new principles during the Neopalatial period happened on a much larger scale than the local dimension considered typical of the invention process (van der Leeuw 2008, p. 242). It also undoubtedly involved a much larger number of agents than the skilled individual whose conceptual and practical breakthroughs are often associated with the concept of invention (Roux 20I0). Bearing this in mind, it has to be acknowledged that the proliferation of the Neopalatial style is somewhere in between innovation (i.e. the progressive adoption of the new set of principles) and the development of a new vernacular tradition (i.e. the definitive integration of these principles within the boundaries of social knowledge).

This raises several questions that are probably all related: when, where, why and how did this invention happen? Moreover, it would be interesting to know why and how this local invention triggered off a wave of innovation. Furthermore, the shift from the proliferation of the new principles to their adoption in a vernacular tradition would also need to be put in its geographical (where?) and chronological (when?) contexts. Of course, this constitutes a challenging area of investigation which demands a much larger and more in-depth 
approach. Nevertheless, some lines of thought can already be put forward as stepping stones for further study.

The major obstacle in the search for invention within the Minoan building tradition is the incomplete state of our data for the stages that precede and follow the Neopalatial period. Architectural remains dating to these periods are less common, and usually their preservation is not sufficient for space syntax analysis to be conducted properly. ${ }^{20}$ Furthermore, in order to be able to grasp variations at the level of the genotype within a building tradition and to recognize these as symptomatic, the analyst needs to study a representative sample. Therefore, by studying the Pre-, Proto- and Postpalatial buildings that are sufficiently preserved, a comparative set has been constituted. Even though this study is still in progress, some preliminary observations can be of some help for the present argument.

In different recent studies, Schoep has investigated further several aspects of social and political organization in Middle Minoan Crete (Schoep 2002; 2004; 2006; 20I0a). She rightly criticized the traditional focus on palatial central authority as the main agent of innovation and change ${ }^{2 \mathrm{I}}$ and argued that this conception was mainly biased by an idea of diachronic homogeneity, the LM II-III palace of Knossos and its associated centralized power being somewhat blindly used as a model for considering the EM III-MM II court-centred buildings (Schoep 2004, p. 244-245; Schoep 2006, p. 38-39; cf. also Dabney 1995, p. 43). ${ }^{22}$ Her main argument is that processes of emulation and competition between different elite groups were the driving forces of the changes that characterize the Middle Minoan period. The MM II town of Malia is central to her argument. Indeed, this site revealed some of the best preserved and published Middle Minoan buildings as well as a considerable amount of material (Poursat 1978; Poursat 1992; Poursat 1996; Poursat and Knappett 2005; Schoep 2002, p. I07-III; Schoep 20I0a, p. 7I-78, for a recent overview of Malia, cf. Driessen 20Iob). In summary, she stressed that the recurrent distribution of similar material assemblages (as well as their associated practices like craft specialization, administration and religious or ideological activities) within different architectural units (Quartier Mu, Villa Alpha, Magasins Dessenne, etc.) pointed to the existence of different social groups - first labelled 'faction' (Schoep 2002, p. II5-I20) and then 'elite' (Schoep 2004; Schoep 2006; Schoep 20I0) - coexisting within the Protopalatial town. Relations amongst these groups

20 Usually in the case of buildings of which the upper floor(s) are missing it is recommended that the precise location of staircases is known for space syntax analysis to be conducted properly (Cutting 2003, p. I8). It is also worth noting that some reticence about the existence of fully developed upper floors in domestic architecture was expressed by several scholars who are more prone to admit the existence of roof terraces instead (Hallager I990; Driessen 2005).

2I This traditional view is crystallized in Cherry's seminal article Polities and Palaces: Some Problems in Minoan State Formation (Cherry I986).

22 It is also worth noting that this analogy could well be doubly doubtful. In LM II-LM IIIA2 Early, Knossos had without a doubt an island-wide administrative, economic and ideological influence. Nevertheless, that does not preclude the existence of regional groups (Chania, Agia Triada, Phaistos) which had the desire and the means to defend their relative political and cultural autonomy from the LM II onwards (Langohr 2009, p. 194-I95). 
"based on affiliation rather than class" would have been characterized by processes of emulation, competition and collaboration in the search for social and material resources (Schoep 2002, p. II8). According to Schoep, the existence of these different groups within the town of Malia should be related to its great - and relatively sudden - expansion at the beginning of MM IB (Schoep 2004, p. 262; cf. also Poursat I987, p. 465). It is generally admitted that, in a process of nucleation, groups came to the settlement and the plain of Malia from elsewhere (Driessen 2001; Schoep 2002). Such a gathering of various groups with different origins "could provide a context for persistent and ongoing factionalism" (Schoep 2004, p. 262; cf. also Preucel 2000, p. 73). On a larger scale and on the basis of settlement patterns and density as well as their respective chronological development, Schoep hypothesized the existence of a "patchwork of large, medium and small polities" with "a marked asymmetry in [their] power relations" (Schoep 2010a, p. 69-70). This power imbalance would have been mediated by the forging of alliances and therefore would have had an important influence on the local elites and their access to non-local resources, thus affecting "the production and consumption of elite culture on the one hand and the dynamics between different elite groups on the other" (Schoep 20I0a, p. 70). Recently, Driessen also devoted a paper to social organization and especially to the 'house' concept (Driessen 20I0a).23 A 'house' is defined as a corporate group which would have been the primary unit of production and consumption within Minoan society and would have defined itself essentially through its locus-boundness and intergenerationality (Pullen 20I0, p. 7; Driessen 20IOa, p. 4I). In other words, 'houses' are social groups of variable size that are practically and symbolically centred on an estate (building or other). This spatial anchorage and the actions involved in its preservation participate in perpetuating group identity and serve "to configure [its] status vis-à-vis other houses within the larger society" (Gillespie 2000, p. 2). The way in which 'houses' and elite groups relate to each other has not yet been explored in Minoan studies, but the two concepts are compatible and could be characterized by a difference of scale, ${ }^{24}$ keeping in mind that the 'house' can be considered "an institution that used multiple strategies to recruit members whose everyday practices integrated kinship, economics, religion and politics (Gillespie 2000, p. I5). The main interest of the 'house' concept for the present discussion is its focus on the "intimate personal relation between buildings and people" (Driessen 2010a, p. 40). ${ }^{25}$

With these concepts and the characteristics of MM II Malia in mind, invention in Minoan building tradition can be reconsidered. In the investigation of the first appearance of the so-called 'palatial' architectural features, Schoep underlined that there was almost no evidence to suggest that the origins of the 'Neopalatial Style' can be traced back to the early

23 For a thorough definition and detailed investigation of this Levi-Straussian concept and its evolution and characteristics, cf. Joyce and Gillespie (2000).

24 With, for example, a 'house' being constituted by higher and lower status individuals (Driessen, pers. comm.).

25 This idea that people invest in space that, in turn, frames the people is of course central in space syntax. 
court buildings at Knossos, Phaistos or Malia (Schoep 2004, p. 245-255; Schoep 2006, p. 39-4I). On the contrary, it is in the MM II settlement of the latter that several buildings testified to the existence of a new vocabulary displaying specific features of Late Bronze Age architecture (Schoep 2002, p. I07-III; Schoep 2004, p. 255-26I; Schoep 2006, p. 4I-42). The innovations included techniques (ashlar masonry, column bases), new architectural modules (such as the Minoan hall, the lustral basin and blocks of magazines equipped with collecting gutters) and new materials (sandstone for walls and white limestone and conglomerate for column bases). Furthermore, elsewhere on the island, there is, for the time being, little evidence for architectural innovations in the Middle Minoan Period apart from Malia (Schoep 2004, p. 259-26I). ${ }^{26}$ Nevertheless, we have to acknowledge the fragmentary nature of our data in contrast to the exceptional preservation of the MM II town of Malia, ${ }^{27}$ as exemplified by Quartier Mu, central to Schoep's argument (Schoep 2002, p. III-II7; Schoep 2004, p. 256-259; Schoep 20I0a, p. 74-78; for a detailed description, cf. Poursat 1992). ${ }^{28}$

Within this complex, Building A is the structure of the MM II town that displays the greatest architectural elaboration by far - with the notable exception of the Crypte Hypostyle and probably the partly excavated Magasins Dessenne (Schoep 20I0a, p. 77). ${ }^{29}$ Indeed, formally speaking, Building A is extremely innovative and could have featured the first prototypes of the Minoan hall and lustral basin in close association (rooms Ir-II3-Irza and I4 respectively - cf. Driessen I982, p. 54-55; Schoep 2004, p. 257; cf. also Shaw 20II, p. I48-I53). Furthermore, structurally its configuration clearly departs from the spatial patterning typical of the Pre- and Protopalatial periods. $3^{\circ}$ If one takes a closer look at Building A with the Neopalatial genotype in mind, some similarities are striking, and it becomes even clearer if the two phases of the building are compared (figures 4 and 5). Indeed, in its second phase (fig. 5), several characteristics stand out: multiple entrances usually associated with external transition spaces (IIII5, Ib, I22, IIId, IIIe), complex ringy system with a typical pole of convergence (cells Irz-Irza) in a dominating position, and tree-like arrange-

26 The northwestern part of the Monastiraki site, characterized by architecture of an official nature, may well be an exception. Even if this building is only partly excavated and not as well preserved as Quartier $\mathrm{Mu}$, it nonetheless testifies to the existence of an elaborate architectural language (possible Minoan hall with a column base in worked stone, door-opening with stone threshold and abutments) elsewhere on the island and perhaps even before the Malian MM II phase (Kanta 2006; Como, Kanta and Marazzi 2009, p. 227).

27 It is therefore more than probable that the emergence of innovations in MM architecture also took place elsewhere than in Malia, the architectural remains found beneath the Domestic Quarter at the palace of Knossos being an excellent example (Evans I930, p. 324-96, and esp. p. 359-6I; Shaw 20II). Unfortunately, such remains are scanty and usually badly preserved.

28 The so-called 'maisons-ateliers' already have their own volume in Études Crétoises (Poursat 1996), but the architecture of Quartier Mu still awaits a final publication. Cf. also Hacıgüzeller and Thaler, this volume.

29 The architectural complex labelled 'Magasins Dessenne' was presumably constituted by two different buildings, probably of a domestic nature (Treuil I999; van Effenterre I980, p. 197-200). Recent cleaning operations and associated architectural studies nonetheless tend to prove that the complex was actually a single building with two architectural phases (Devolder, forthcoming).

30 On Building A, cf. Hacıgüzeller and Thaler, this volume, for a detailed configurational analysis. 

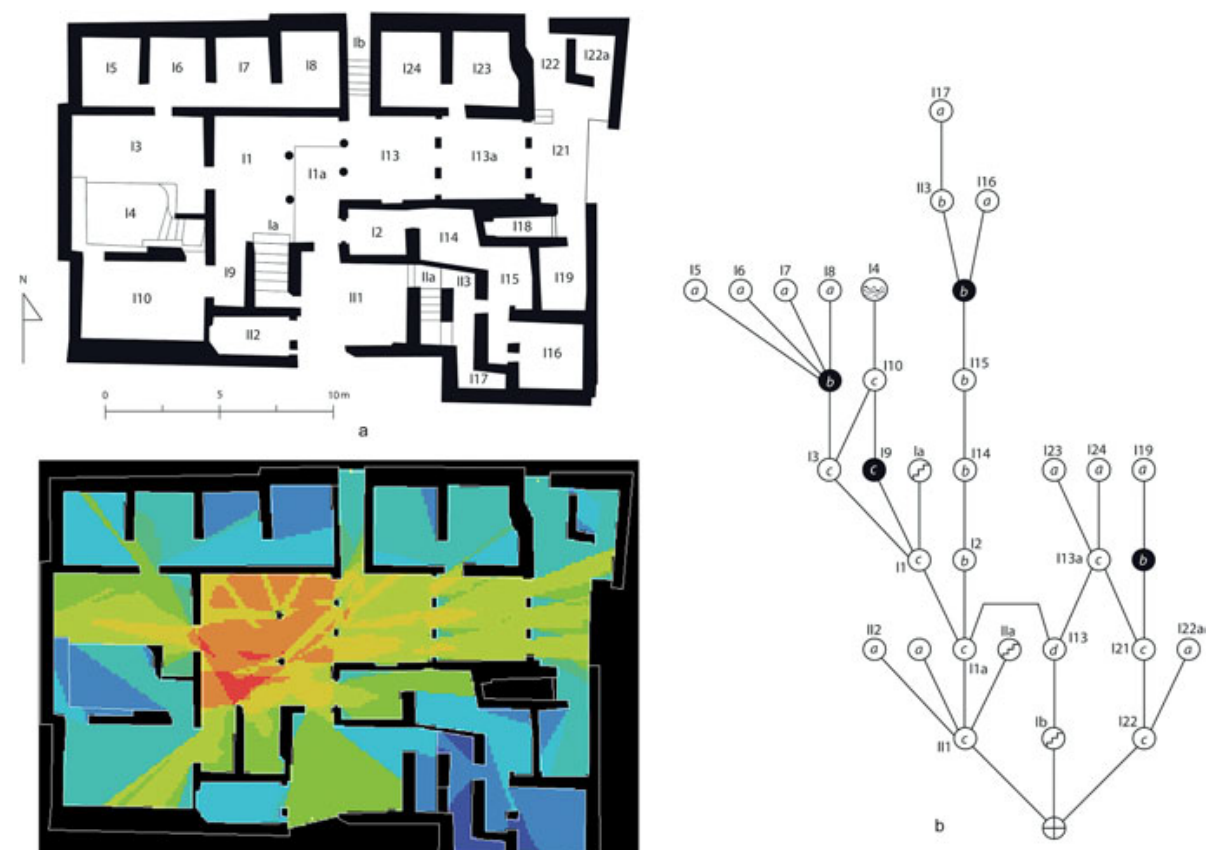

Figure 4 | Quartier Mu - Building A - $\mathrm{I}^{\text {st }}$ phase - Plan (a), j-graph (b) and visual integration (c).

ment of spaces beyond the distributed parts of the complex. A very good example of the symmetrical pattern of the latter is found in the more systematic organization of storage spaces along a corridor giving access to them (Poursat I992; van Effenterre I980, p. I79-I80), which prefigures one of the most typical spatial configurations of storerooms in the Neopalatial period (Begg I975, p. I9-2I; Christakis 2008; Treuil I996). ${ }^{\text {I }}$ Add to these symptomatic configurational features some of the first documented uses of architectural techniques such as pier-and-door partitions (polythyron), cut stone door jambs, ashlar masonry, usually considered characteristic of the Neopalatial period, along with the embryonic versions of a lustral basin and a Minoan hall, and it does seem attractive to consider Building A of Quartier Mu as an appropriate background for invention within Minoan building tradition. Moreover, the articulated nature of the configuration of Building A strongly contrasts with the simple agglutinative structure of the MMIA/B houses that existed south of the 'palace' (Driessen 20Iob, p. 560). However, it has to be admitted that, to a certain extent, because of its exceptional conservation, Quartier Mu might be somewhat artificially singled out. Indeed, the existence of buildings with similar elaboration else-

3I The same type of storage spaces is also attested in the Magasins Dessenne, the Crypte Hypostyle and in the east wing of the court building or 'palace' (Schoep 2004, p. 259). 

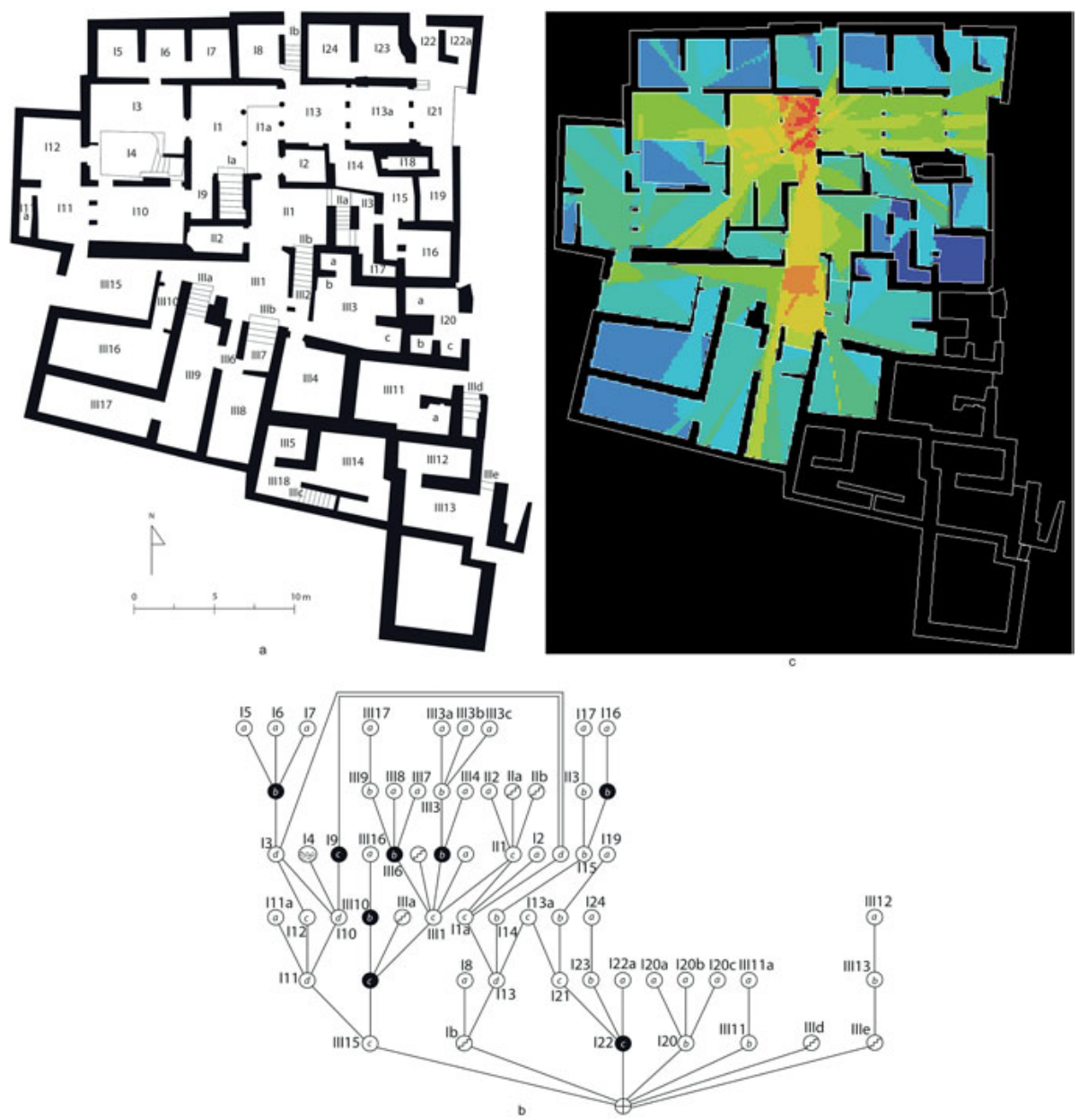

Figure 5 | Quartier $\mathrm{Mu}$ - Building A $-2^{\text {nd }}$ phase - Plan (a), j-graph (b) and visual integration (c).

where during the end of the Middle Bronze Age cannot be ruled out.32 For example, it has been argued that a similar plan may have existed in the Throne Room area at Knossos as early as the MM I-II period (Mirié I979; Niemeier I987; Dickinson I994, p. I49-I50). This hypothesis is a matter of debate and is strongly criticized by Schoep, who considered that these attempts to put the origins of the Throne Room in the Protopalatial period are clearly influenced by "the desire to project back later functional and architectural elements" and are contradictory to more recent stratigraphical and architectural investigations (Schoep 2004 , p. 249, see also Macdonald 2002, p. 42). It is also interesting to note that Building B (Poursat I992, p. 24-3I), built slightly later than A (Driessen 20Iob, p. 562), shows a much

32 Cf. n. 26-27 above. 

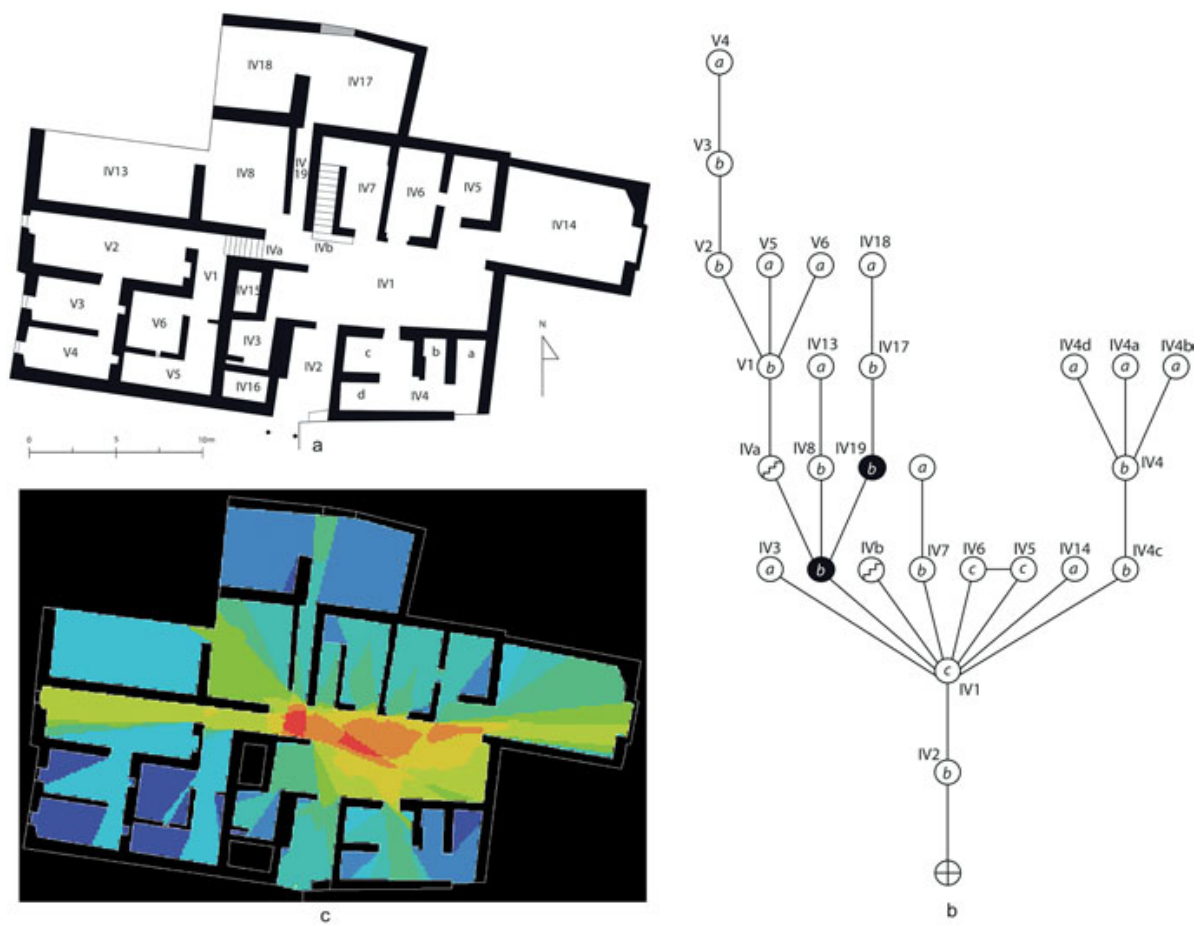

Figure 6 | Quartier Mu - Building B - Plan (a), j-graph (b) and visual integration (c).

more agglutinative arrangement, with many rooms opening directly onto space IVI (fig. 6). The latter, the central hub of the building, is the most integrated space, has high visual controllability and lies on a limited internal ring (with spaces IV6 and IV5). Beyond this ring, all spaces are organized in linear sequences. This gives the impression of being a more functional building, mostly dedicated to storage, with IVI acting as a controlling point for taking goods in or out.33 Nevertheless, since the entire west part of the ground floor is gone, we need to be particularly cautious with remarks on configuration. Furthermore, the presence of a paved vestibule with a bench (IV2) and some finds of really good quality in the destruction layers in the basement-like spaces to the west (Poursat I992, p. 29) could potentially suggest a different reconstruction of Building B.

On present evidence, MM II Malia in general and Building A of Quartier $\mathrm{Mu}$ in particular may have been one of the cradles of architectural invention within Minoan building tradition. This could thus contribute to answering the 'where' and 'when' questions. But

33 This close association between a more 'prestigious' and a fairly 'functional' building was identified as a recurrent architectural pattern in Minoan architecture, especially in the Neopalatial period, with Tylissos (buildings A and B) and Knossos (Little Palace and Unexplored Mansion) being the most famous examples (Preziosi I983, p. 72; Poblome and Dumon I987-1988; Hitchock and Preziosi I997). 
what about the 'why' and 'how'? Before tackling these issues, it is worth remembering that the Protopalatial period (especially MM IIB and MM III) also witnesses the appearance of terracotta house models (Schoep I994; Schoep 2004, p. 262), some of which, like that found in Archanes (Lembessi I976), were extremely detailed, mapping circulatory patterns that became typical of the so-called "Neopalatial style" (Palyvou i987, p. I96). As was pointed out by Glassie, plans are indications of cultural distance: "The amount of detail on a plan is an exact measure of the differences that separate those who conjoin in a building project" (Glassie 2000, p. 45). House models such as that of Archanes could betray the existence of individuals whose chief function was to design new types of buildings and give indications about how to build them. 34 This could then attest a break in the full congruity between design, construction, and use in that some specialized agents may have been in charge of the design and planning, whereas construction and use remained with unspecialized individuals, probably the future inhabitants of the building. Some of these matters will be dealt with when considering the innovation process, but the reasons why and the ways in which invention happened in MM II Malia should first be considered.

Schoep related the application of what she coined 'innovative architecture' in elite residences to the deployment of conspicuous consumption, an important strategy in elite competition (Schoep 2004, p. 262). It is, however, difficult to determine if conspicuous consumption in the built environment should be held responsible for invention per se or more simply for the small-scale proliferation of these new ideas - and thus innovation - within the MM II town. It is nonetheless a possibility that a specific elite group, in an attempt to make itself distinct, set a wave of innovation in motion by initiating the creation and enhancement of several building features and spatial patterns, for example in Quartier Mu. The conscious modification of the traditional genotype of the built form (i.e. invention) illustrated in the latter could, however, betray something more fundamental. What clearly stands out from the configuration of Quartier $M u$ is a redefinition of the interfaces, a term that, in space syntax, defines the relational patterns between the two categories of users of a building, the residents and the visitors (Hillier I996, p. 25I).35 Indeed, the spatial organization of Building A shows strong articulation: many rooms are separated by transition spaces and tend to be clustered in sectors (magazines to the North and South, ceremonial and hosting areas in the middle, basement storage in the south-east: Poursat I992, p. 3I-47, fig. 40). ${ }^{36}$ A concern for efficiency could account for this situation, but this type of segmentation is often related to increasing socio-political complexity (Kent I990). Space is segmented in that rooms hosting compatible and/or complementary activities are clustered, while some specific rooms (or sets of rooms) are kept apart from each other to avoid interference between activities and practices considered irreconcilable. The high segmentation

34 For an exhaustive discussion of house models in antiquity, cf. Muller (I998).

35 Cf. also n. I5 above.

36 This is what Hacigüzeller and Thaler (this volume) call 'compartmentalisation'. 
of Building A therefore betrays the existence of more complicated interfaces than what usually exists in the agglutinative mode of organization space recurrent in the Pre- and Protopalatial periods. 37 This is exactly what Schoep noted when acknowledging that the "innovative architectural features not only marked wealth and status, but also, through their deployment in various internal and external locations, functioned to include and exclude different groups of people" (Schoep 2004, p. 262). She established a close connection between these new spatial patterns and the staging of gatherings and/or ceremonial activities (Schoep 2004, p. 262-263; cf. also Letesson and Driessen 2008). Apart from their form (embryonic Minoan hall), the syntactical properties of the arrangement of spaces Ira-Irz-IIza make it the perfect candidate for a hosting/gathering area, a true pole of convergence (fig. 5). Indeed, these spaces are syntactically and visually integrated, while room Irza, in particular, is situated in a dominant position on an external ring, a property that is usually associated with the mediation between the interior and the exterior of a building (and therefore between residents and visitors: Hillier and Hanson I984, p. I58-I59; cf. also Letesson 2009, p. 347)..$^{8}$

Thus, besides external gathering areas that have a long history in Minoan Crete, in funerary contexts (Branigan I993; Branigan 1998; Hamilakis 1998; Murphy 1998), natural places such as caves, hilltops and mountain peaks (Haggis I999, p. 73-79; Tomkins, forthcoming), and settlements (Driessen 2004; Murphy 20IO; Todaro 20I2; Tomkins 2007, p. I87-190; Tomkins 20I2; Tomkins and Schoep 2010, p. 73-74), with the central part of Building A, the fabric of the built form itself revolves around a gathering space.39 Apart from its configurational properties and spatial features, the central part of Building A also revealed a large amount of fine tableware with the largest concentration of drinking vessels in polythyron II3 (Poursat and Knappett 2005, p. I99; Schoep 2010a, p. 77). Quartier Mu could very well be the first known example of the clear absorption within the built environment of gathering practices and commensal activities traditionally associated with the exterior world (Letesson and Driessen 2008, p. 210).40 This "appropriation of the commu-

37 This corresponds to what Dabney labelled a switch from an undifferentiated to a differentiated disposition of space in non-palatial buildings (Dabney I995, p. 46).

38 The same probably goes for rooms IIII and especially III, which was the major entrance during the first phase of the building. Both of these spaces also formed a kind of buffer zone between the north and south parts of Building A during its second phase and certainly had a pivotal role in the distribution of the circulation, both horizontal and vertical, by means of the surrounding staircases (IIa, IIb, IIIa and IIIb).

39 At the same time, it seems that the central court of Knossos, Phaistos and Malia was not fully circumscribed (Schoep 2004, p. 252-255; Schoep 2006, p. 4I, n. 45) and that the south wings were built later during the Neopalatial period (cf. also Letesson and Vansteenhuyse 2006, p. I08-IIO).

40 Even if Schoep underlined that those ceremonies have left few or no traces (Schoep 20I0, p. 77), the new spatial syntax of their architectural settings might well be the best testimony of their existence. These smaller-scale gatherings hosted by specific elite groups were certainly of a different nature than the events happening within the court building, which probably involved the community at large. "This seems to mark an important change from previous periods when the court building may have been the primary arena for social interaction between different groups" (Schoep 2004, p. 264). 
nal" (Tomkins and Schoep 20Iо, p. 76) can be explained by a growing concern about the control of such events that could promote "a feeling of group identity amongst those who were invited inside" and be manipulated as a "strategy of exclusion marking the lesser status of those excluded" (Schoep 2004, p. 263). It is difficult to decide if the new interfaces crystallized by this architecture involved either competing elite groups (inner/real and sub/ aspiring-elite: Schoep 20I0a, p. 74-78), different components of a 'house' that can be quite heterogeneous, being characterized by the fact that there is no typical form of affiliation to it (Driessen 20I0a, p. 4I; Gillespie 2000, p. 7), or more simply a combination of both with a privileged social group and its affiliates or dependents. One thing is certain, though: this invention at the level of the spatial structure echoed a significant change in the social matrix. To summarize, it seems that the relations amongst competitive social groups within the same town led to the need for new social and cultural arenas and therefore for new spatial arrangements materializing them. The contacts between those different groups and sub-groups intensified, and consequently, better controlled and segmented built forms arose, while some groups probably used these architectural innovations to advertise their social superiority and establish their political power.

If the previous discussion can contribute to clarifying the reasons why invention happened, it does not say much about the ways in which it was made possible. First of all, we have to take into account the fact that architectural invention took place in a "wider context of technological innovations in MM II, including the use of the potter's wheel and an elaborate administrative system" (Schoep 2004, p. 264). The town of Malia in MM II, with its numerous traces of specialized crafts in many buildings (Schoep 2002, p. II5-II6), gives the impression of a hive of artisanal and industrial activities. In this context, the competition between workshops and/or craftsmen affiliated or offering their services to rival social groups could have been really high. One can easily imagine that these talented individuals were vying in skill and daring with each other, relentlessly exploring new ways of making things, addressing new challenges to the technological system and, eventually, profoundly improving the know-how of their time. Furthermore, it is generally accepted that long-distance exchange and contacts were relatively frequent in MM II and were certainly not only related to the involvement of a palatial authority (Schoep 2006, p. 48-49). As it was already the case in the Prepalatial period (Tomkins and Schoep 2010, p. 70), independent agents were in contact with the Cyclades, Egypt and the Near East. Consequently, external influences had a clear impact on Crete with the selective adoption of technologies borrowed from the East during EM III-MM II and probably mobilized by competing elite groups to establish their claim for power and affirm their superiority (see Schoep 2006, p. 52-57 for a detailed examination). These eastern technologies made their way into many aspects of material production, and buildings were not an exception. Apart from more architectural innovations (use of ashlar masonry, orthostats and column base), it has been suggested that the Minoan hall and lustral basin could have been of Egyptian inspiration (Graham I977, p. I24-I25; Driessen 1982, p. 55; Schoep 2006, 
p. 55-56).4I In Malia, imports - whether foreign or Cretan - are more common in MM II than in any other phase of the settlement's history (Driessen 20Iob, p. 56I). If we take into account this atmosphere of technical emulation and eastern influence, Quartier $M u$ with its maisons-ateliers, the production of which it was probably closely overseeing (Poursat 1996; Schoep 20I0b, p. I2I), and its Egyptianizing items (Poursat I992, p. 26; Schoep 2002, p. II8-II9) could definitely be a privileged backdrop for architectural invention.

For the time being, this specific role of Quartier $M u$ in the process of architectural invention within Minoan building tradition should be considered a working hypothesis and needs to be tested on the basis of other evidence. For example, some Early Bronze Age (MM I/Prepalatial) buildings often considered unusual, such as the oval structure at Chamaizi (fig. 7, cf. Davaras 1972; Davaras 1992; Lenuzza 20II) and the large building at Agia Photia (fig. 8, cf. Tsipopoulou I988; Tsipopoulou I992),42 already showed a configuration that in some aspects remind us of Quartier $M u$ and the future Neopalatial genotype (external distributed part and internal tree-like sequences with the pole of convergence, a large central space in a dominant position on an external ring, as liminal cell and buffer zone). The existence of such spatially elaborated buildings in the Prepalatial period showing configurational properties that seem to presage the later genotype proves that the social evolution of the Middle Bronze Age is certainly not a total departure from what happened in the Early Minoan period (Tomkins and Schoep 2010, p. 68). ${ }^{43}$ Of course, throughout history such configuration is recurrent in many vernacular traditions (cf. for example the Kuanyama kraal of the Ambo Tribe: Hillier and Hanson 1984, p. I63-167) and should not be considered to be too symptomatic. The conjunction of many more recurrent factors is needed for a definite genotype to be established. Furthermore, during the same period, more modest domestic structures, such as Block B in Myrtos Fournou Koriphi (fig. 9, cf. Warren 1972; Whitelaw I983; Sanders 1984; Sanders 1990), have nothing to do with this type of configuration and testify to the classical agglutinative way of organizing spaces. Nevertheless, this remark proves that a systematic structural study of the whole Minoan built environment is needed in order to have a better understanding of its evolution and revolution.

4I Following the same line of thought, the introduction of three-dimensional terracotta house models in MM II could point towards a Near Eastern or Egyptian influence (Schoep I994, p. I98).

42 It is also worth noting that a substantial amount of the material found in the Agia Photia cemetery is compatible with a Cycladic source of manufacture and therefore attested to the existence of contacts between the Cyclades and the north coast of Crete (Day, Wilson and Kiriatzi I998). Furthermore, it is not impossible that these links to the Cyclades might be indicative of the origin of the local community in historical terms (Day, Wilson and Kiriatzi I998, p. I47). Bearing that in mind, we have to continue to be aware that external influences may well have played a decisive role in the elaboration of the large building at Agia Photia.

43 Even if distinct social groups might well have been slightly more homogeneous, apart from each other, in smaller settlements with only episodic and brief trading contacts, and even if social competition mainly took place in different arenas (the highly visible forms of burial, for example), these buildings could attest to a more segmented and articulated use of space, also revealing an "appropriation of the communal" by some dominant groups that was already underway (Tomkins and Schoep 20I0, p. 76). 

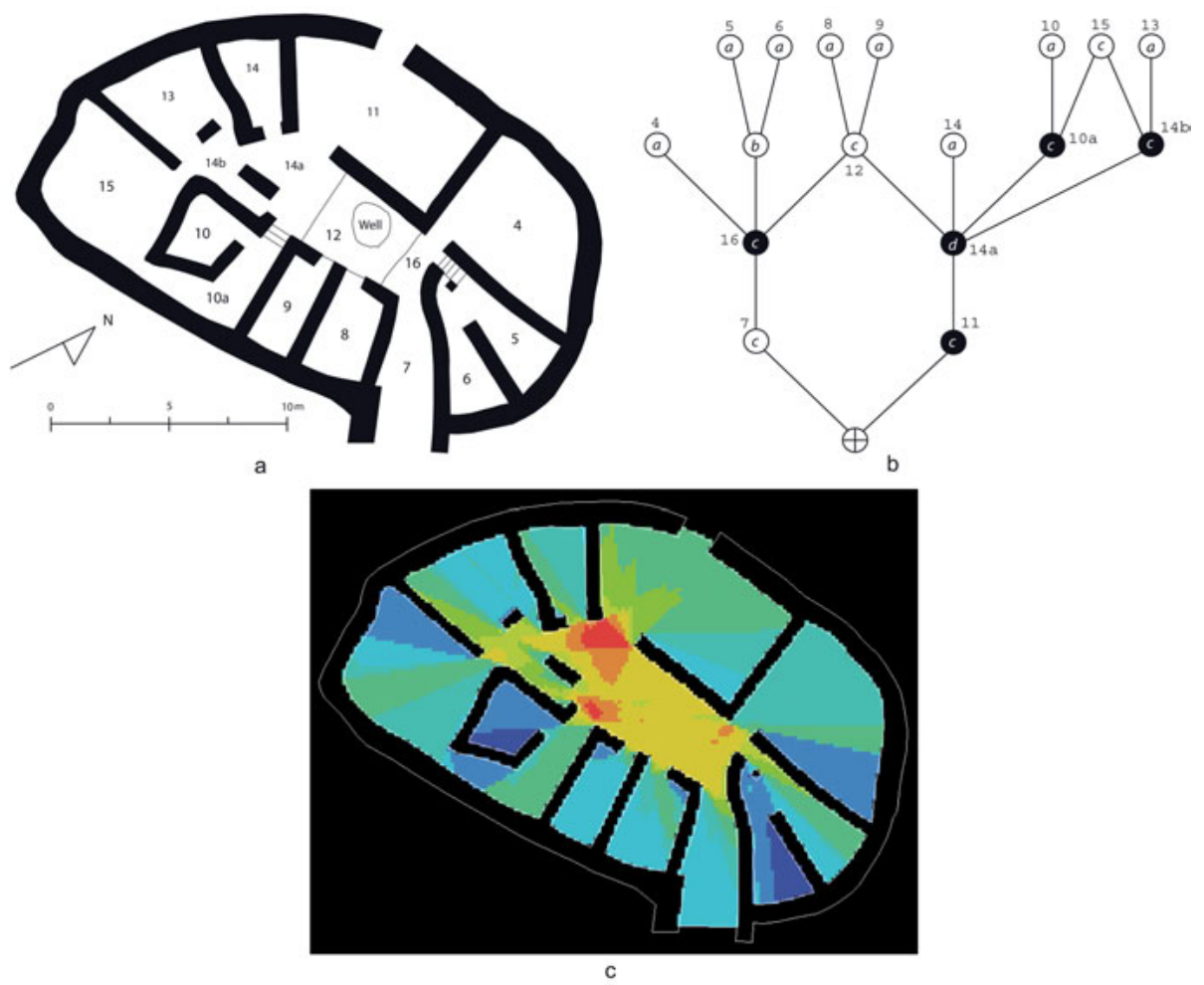

Figure 7 | Chamaizi - Plan (a), j-graph (b) and visual integration (c).

After examining the process of invention in the context of MM II Malia and Quartier $M u$ particularly, the widespread proliferation of these new principles remains to be addressed. Radiating from its birthplace, this innovation happened at different scales with variable intensity, throughout Crete first and in the Cyclades and mainland Greece afterwards (Shaw 2009, p. I69-I78). Traditionally, the direction of the influence has always been considered to go from the 'palaces' to other buildings (Driessen I989-I990). It is now felt more likely that burgeoning features of the Neopalatial genotype first appeared outside the court-centred buildings. 44 Their proliferation over the island in the Late Bronze Age has been interpreted differently (for references see Schoep I999, p. 202, n. 3). One hypothesis closely related to the direction of influence traditionally mentioned - considers that the large-scale distribution of the 'palatial' features reveals an integrated political landscape centred on Knossos, with lower order centres repeating, on a less grandiose scale, the func-

44 This does not preclude the fact that the evolution of these new architectural techniques and spatial patterns might have been punctuated by developments originating in the court-centred building and in non-palatial buildings. 

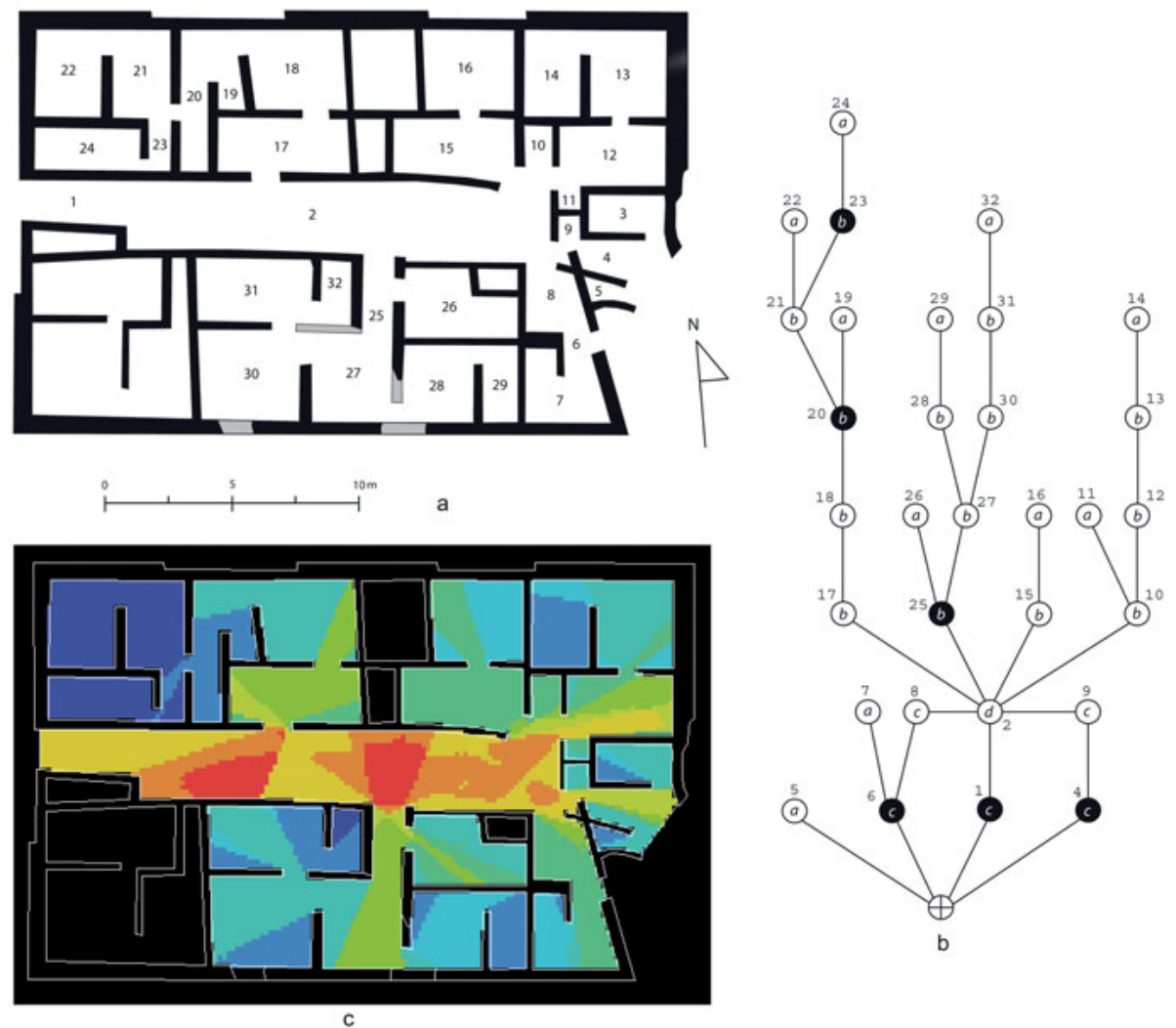

Figure 8 | Agia Photia - Plan (a), j-graph (b) and visual integration (c).

tions exerted by the capital. A second school of thought explains this proliferation as resulting from interaction and emulation between independent peer polities (Hamilakis 2002). Whatever its reasons, this phenomenon certainly followed complex trajectories and developed through different scales that all deserve thorough consideration if we wish to be able to understand this wave of innovation properly. The circumstances that favoured the proliferation and the means of propagation have to be considered from the settlement level to an island-wide perspective and even further away with the Minoanizing architectural features attested overseas. Usually such a phenomenon is considered from a top-down angle but, in the case of the widespread adoption of an invention which is first and foremost a local process, it seems more sensible to reverse the perspective by adopting a bottom-up approach.

Where the settlement level is concerned, we should again return to the MM II town of Malia. The situation of the Middle Bronze Age town was probably rather similar to what Cunningham has identified for Palaikastro, where the street grid was first laid out in MM II (Cunningham 200I, p. 79; MacGillivray and Driessen I990, p. 390-40I; MacGillivray and Sackett 20IO, p. 574). Even if some architectural remains are as old as EM II (van Effenterre 

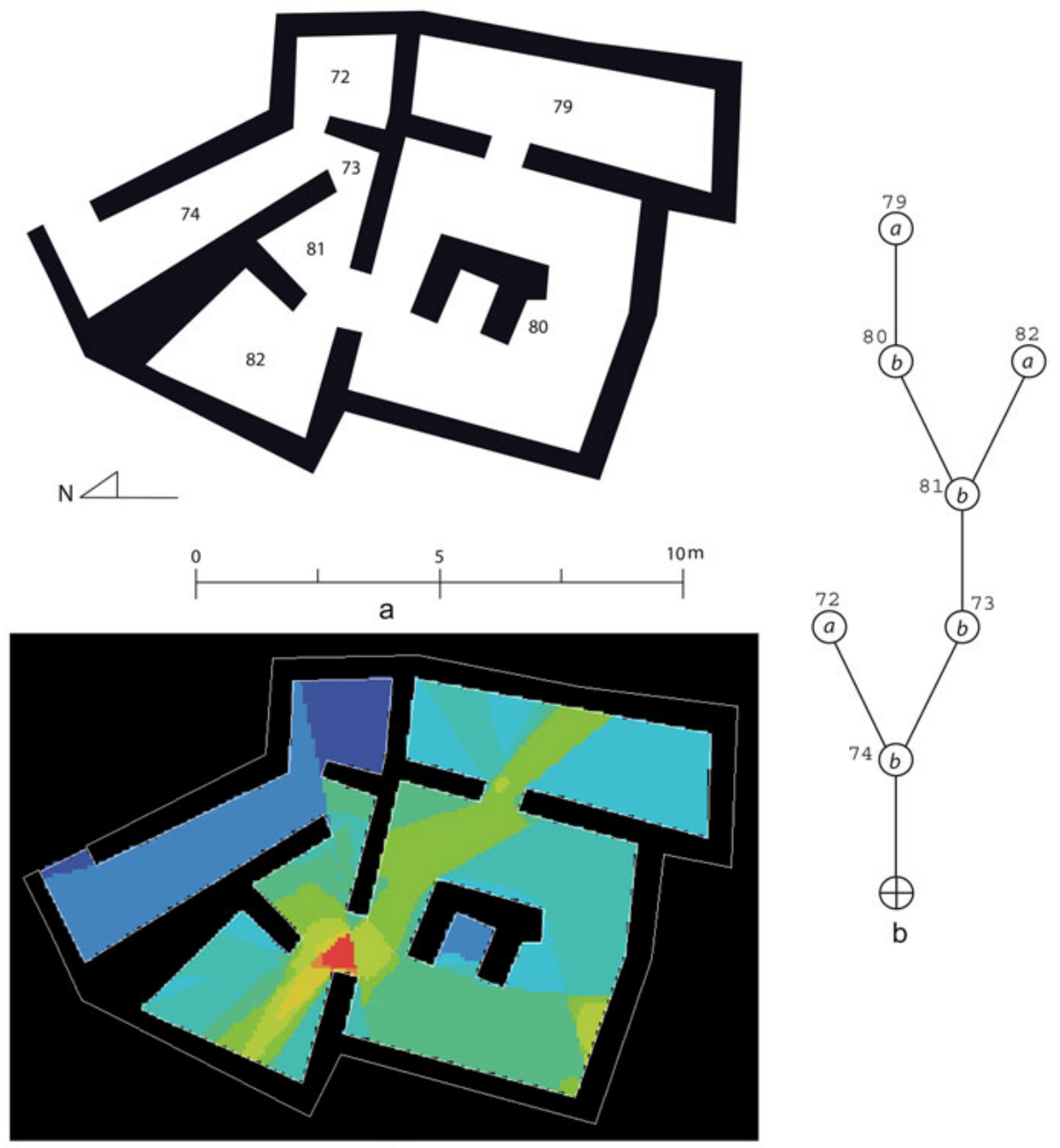

C

Figure 9 | Myrtos Fournou Koriphi - Block B - Plan (a), j-graph (b) and visual integration (c).

I980, p. 29-30 and $155^{-156)}$, it is only in MM IA that a coherent street system was laid out around building blocks (van Effenterre I980, p. 26I; Driessen 20Iob, p. 560 ). 45 If the configurational features mentioned above are added to these urban characteristics, Malia seems to display significant signs of stress incurred when population density and settlement size approach a certain threshold of tolerance involving frequency of interaction and

45 It is also possible that, at the time, an enclosure wall protected the town. The latter is attested at several points, but its line cannot be followed everywhere (van Effenterre I980, p. 22 and 265-267; Deshayes and Dessenne I959, p. 4-5; Driessen 20Iob, p. 560). 
difficulty of communication (Fletcher I995, p. 69-162). Cunningham also identifies different features that all point to the presence of such a problem at Palaikastro: placement of central rooms away from the street, serial segregation of internal spaces, street system facilitating large scale communication, and use of more durable materials (such as ashlar: Cunningham 200I, p. 82).46 It does seem that the two towns were in a very similar situation. If we can admit that the birth of new architectural features and spatial patterning was influenced by the attempt by certain groups to raise themselves above others and to create appropriate arenas for promoting and maintaining their superiority, we cannot exclude the major impact of the spatial response to social stress. In practical terms, even if the social group in charge of Quartier $\mathrm{Mu}$ initiated a new spatial vocabulary in a context of conspicuous consumption and inclusion/exclusion practices in Building A (Schoep 2004), this does not prove that it was more due to elite competition than to social stress. In fact, it makes a lot more sense to allow for both processes to be involved in the birth of new spatial requirements and therefore architectural forms. As Cunningham pointed out: "One of the predicted responses [to social stress] has to do with the need to project a unifying social message. This can perhaps be seen on an individual scale with the use of a common repertoire of elite signifiers" (Cunningham 200I, p. 82).47 Of course, the same goes for the adoption within the town of Malia of these new features: other social groups, in other buildings, were probably not only imitating the elite behaviour taking place in Building A (Schoep 2006, p. 58), but were also simply affected by the same social stress with the same consequences: stronger articulation of the configuration, allowing better control of access and categorization of internal spaces. This probably resulted in more complex and controlled interfaces with different types of users having different rights according to their social status, age, gender, etc. It is also worth noting that similar social contexts could cause rather different spatial responses at a variable pace. Furthermore, some spatial responses chosen by a community could well be completely rejected by another, as attested by the fate of the Minoan hall in area 6/block M in Palaikastro (Driessen 1999; Knappett and Cunningham 2012, p. I2-I5), which would give its preference to more local forms (e.g. the so-called Palaikastro halls: Driessen I989-I990, p. I4; Driessen 1999). It is also worth mentioning that, in the process of innovation, it is very often the context of the invention which is chosen rather than the technique itself (Roux 20I0). This means that, in the case of MM II Malia, for example, social groups may have wanted to imitate the general model of inclusive/exclusive practices of Building A in Quartier $\mathrm{Mu}$ and not specifically the articulated plan that materialized them. This accounts for some variability in their own buildings that were not aping

46 In his analysis, Cunningham made use of several space syntax concepts for approaching both the urban layout and the buildings' configuration (Cunningham 200I, p. 79-8I).

47 One of the other responses is the creation or enhancement of monumental public buildings which likewise provide a clear isovistic message across the increasingly large and complex interaction-communication field (Fletcher I995, p. I34-I5I). The progressive investment in the court-centred building of Malia from MM II to its heyday in the Neopalatial period is probably good testimony to this process (cf. for example Schoep 2006, p. 58). 
spatial configuration and architectural features stricto sensu. Hence, while investigating the diffusion and adoption of new architectural principles and patterns, we have to remain open to the existence of complementary, divergent or reactionary dynamics. Of course, this applies to the whole scale-spectrum.

Locally, growing social stress could well help to explain the diffusion of the new architectural principles, but on a larger scale some other processes are more than certain to have been at stake. When considering the island level, it is good to bear in mind that the two schools of thought mentioned might not be as contradictory as it seems at first sight. Indeed, even if the existence of a more politically integrated landscape with some centres extending their control over neighbouring polities is accepted for the Protopalatial period (Tomkins and Schoep 20I0, p. 73), this does not preclude the existence of emulation between different centres or even between smaller polities within the authority of the same centre. It also seems clear that "the scale and complexity of a center (size of main settlement, number of large complexes, social hierarchy, competition, etc.), and its access to interregional networks have an influence on the originality and complexity of elite culture." (Schoep 20I0, p. 78). In the literature, instead of the centre imposing its cultural norms onto its subordinate settlements (which of course probably happened for some aspects and in specific periods), the emulation process is often related to smaller settlements adopting (import) or adapting (local production) aspects of the elite culture of larger polities. Wellknown examples of this are the settlements of Myrtos-Pyrgos and Monastiraki and their relation respectively with Malia and Phaistos, as attested by their adoption and use of writing and administration as well as their production and consumption of fine tableware (Knappett I999; Kanta I999; for other examples cf. Schoep 2010, p. 78-79). As was already stated, these processes of emulation, adoption and adaptation can follow complex dynamics. The adoption of some cultural traits does not guarantee that one social group would borrow the full cultural package of another. Moreover, over time, the channels of influence can change direction or simply flow from another source. For example, we may wonder why Myrtos-Pyrgos, usually considered to be within the cultural influence of Malia in the Protopalatial period, looks so Knossian, architecturally speaking, in the Neopalatial period, especially where its main building is concerned (amongst other features, we can note the presence of gypsum dadoes, a gypsum bench with triglyphs, special attention given to colour alternation, a stairwell with balustrade and columns, etc.: Driessen I989-I990, p. I5; Chlouveraki 2006, p. 288-293). The emulation processes aside, some other factors could have played a decisive role in the diffusion of the new spatial patterns and architectural features. In his description of the Minoan 'house', Driessen emphasized that 'multilocal house groups' could have existed, "dispersed over a series of even nonadjacent communities, and thus contributing to a social and symbolic landscape that exists within and through the identifiable settlement network" (Driessen 20Ioa, p. 55). He stresses that this could contribute to explaining "the progressive dispersal of seal types from the core area to surrounding villages during the late Prepalatial and early Protopalatial 
period" and even in outlying areas on the island, if not beyond, at a later date (Driessen 20Ioa, p. 56, n. 22-24). This could also, at least in part, account for the wave of architectural innovation on the island and perhaps overseas. Various groups stemming from the same 'house' but geographically apart from each other could have therefore stimulated and taken part in the mobility of architectural technology to create similar adequate - in the sense that they would have materialized the same social interfaces - buildings at various points on the island. Similarly, Driessen recently associated several mason's marks found in courtcentred buildings with the work and presence of different 'house' groups within these communal centres (Driessen, forthcoming). $4^{8}$

Besides the reasons why this wave of innovation took place, the agents that conveyed the new principles have to be briefly considered. Buildings are the settings of daily life, they are at the same time the materialization of cultural norms and the arenas where the latter are maintained, negotiated and reproduced. Because of this specific nature, they are more prone to conservatism than other aspects of material culture. This could of course account for the time lapse that separates the birth of architecture in MM II (presumably in built environments like Quartier $\mathrm{Mu}$ at Malia) from the progressive diffusion of the new principles and their crystallization in the form of a new vernacular tradition, probably at some point during the Neopalatial period. Of course, in these processes and their relatively long time-span, the vectors of diffusion also have to be taken into consideration. The hypothetical existence of 'specialized supervisors' (Shaw 2009, p. I68) was related to the innovation process that characterized the Neopalatial period. Itinerant builders with a high level of expertise were put forward as a way of explaining how the 'Neopalatial style' spread throughout Crete and especially to remote and small-sized settlements (Driessen I989-I990, p. I7-22; Shaw 2009, p. I66-I69). Unfortunately, as Shaw puts it: "Without adequate contemporary records, our understanding of the organization of the builders and their relationships to those in charge of the building, whether patrons, administrators or experienced supervisors, is limited to reasoned speculation" (Shaw 2009, p. I66). Likewise, house models might also have served as diffusion devices: they could have been carried along by travelling craftsmen to promote their work and abilities, sent towards some subordinate settlement by a larger centre to sustain a political message, or kept as a token of affiliation and/or remembrance by a 'house' group away from its focal place.

Most of the above mentioned processes probably played a role on a larger scale in the diffusion of this 'Neopalatial style' in the Cyclades and even the Greek mainland (for various examples, cf. Shaw 2009, p. I69-I78; Palyvou 2005, p. I79-188). A detailed investigation of the architectural minoanization of the Aegean is beyond the scope of this paper.

48 This idea of mason's marks being associated with different groups is not new, but usually they are linked with gangs of workmen responsible for completing adjacent projects within the court-centred buildings (Begg 2004a, p. 20 and n. I66 for a historiographical approach to this idea; Begg 2004b, p. 22I; more generally on mason's marks, cf. Shaw 2009, p. 76-79). 
Nevertheless, some general remarks can be made. At the beginning of the Late Bronze Age, Cretan elite culture was probably well known in the Aegean and mobilized by foreign elite groups to establish their own superiority. However, it is also possible that, during the Neopalatial period, some 'house' groups left Crete under the pressure of increasing rivalries between 'houses' (Driessen 20I0a, p. 55). These settlers could have been forced to leave their focal place but kept the firm intention of re-creating it somewhere else (or at least of importing some of its features as symbolic links with the ancestral 'house'). All these phenomena could have taken part in the widespread diffusion of the new Neopalatial vernacular tradition overseas. As for the lower scales of diffusion, we need to remember that these processes usually follow complex dynamics, with an intricate interplay of external influence and local tradition, adoption and adaptation, resistance and affiliation.

\section{Postscript}

In the light of this research, it appears that the so-called 'Neopalatial Style' in Minoan architecture has to be considered a phenomenon which developed from progressive innovation (i.e. adoption of new principles) to the emergence of a new vernacular tradition (i.e. new principles becoming cultural standards). Invention (i.e. creation of new principles) certainly happened before the beginning of the Neopalatial period - perhaps notably in MM II Quartier $\mathrm{Mu}$, as tentatively suggested here - and may have been influenced by the longterm maturation, adaptation and transformation of even earlier architectural developments. As Glassie stated: "No building is entirely new. If it were, it would be utterly incomprehensible. [...] No matter how grandiose and revolutionary the creation, there must be some tradition, some presence of the common and continuous - of the qualities called 'folk' - or people would not be able to understand it or use it. In their mixing of the old and the new, all buildings are vernacular, the products of real people in real situations" (Glassie 2000, p. 70).

This paper does not present a definitive picture of the evolution of Minoan architectural language. Some questions were tackled, others were raised, but most importantly, a new way of considering the evolution of the built form in Minoan Crete was advocated, a way that does not only focus on architectural forms and functions but gives a central place to the analysis of configuration, the structure of space. Through its application to several key buildings in Minoan architectural history, it can already be realized that space syntax, with its invaluable potential for comparative analysis, definitely constitutes a powerful tool for investigating concepts of invention, innovation and diffusion. This paper should hence be considered as a first step to a much needed diachronic and systematic structural approach to the Minoan built environment.

Some remarks and perspectives for further research may be offered in conclusion. In this paper, quite traditionally, buildings were mainly approached as products, as definite 
architectural forms. Nevertheless, we must be aware that this pre-eminence of form over process, clearly dominant in Western thought, may not be the most efficient paradigm to deal with the evolution of built structures. Indeed, architecture comprises at once process (acts) and results (products), but as Blier noted, buildings are first and foremost living organisms (Blier I987, p. 2; cf. also Hillier 1996, p. I7-20).49 They "have life-histories, which consist in the unfolding of their relations with both human and non-human components of their environments" (Ingold 2000, p. 187). Hillier concurs when he writes: "The built environment is, apart from society itself, the largest and most complex artefact that human beings make. Its complexity and its scale emerge together, because, like society, a built environment is not so much a thing as a process of spatio-temporal aggregation subject to continual change and carried out by innumerable agencies over a long period of time" (Hillier 1996, p. 92). Therefore building is an ongoing process: "It does not begin here, with a pre-formed plan, and end there, with a finished artefact. The 'final form' is but a fleeting moment in the life of any feature, when it is matched to a human purpose, likewise cut out from the flow of intentional activity" (Ingold 2000, p. I88). This shift in perspective from products to process corresponds to what van der Leeuw labels a shift from a static to a dynamic world view, a perspective where one does not study 'what is' but 'what happens', not entities but processes, where change is assumed and stability needs to be explained rather than vice versa (van der Leeuw 2008, p. 226). Van der Leeuw also considers this dynamic world view to be 'non-linear' in that it turns its back on linear causalities, acknowledging unexpected behaviour as happening in otherwise regular processes. "Moreover, from this perspective, similar causes can have widely divergent effects, but very different causes can, under certain circumstances, also have convergent effects" (van der Leeuw 2008, p. 226). In such a non-linear dynamic approach, discontinuity and bifurcation are seen as intrinsic properties of complex human systems, whose resilience and continued existence depend as much on innovative behaviour as they do on replication (van der Leeuw 2008, p. 227). Such an approach could turn out to be particularly well adapted to the study of the evolution of the Minoan built environment (for a similar plea, see Driessen 20Ioa, especially p. 43-46). Unfortunately, the state of preservation of our data is a major issue. Remains of Minoan buildings are usually in a rather bad state, and even when they are not, documenting their modifications in plan and structure is far from easy. Nevertheless, special attention given to architectural phases and, more precisely, a diachronic approach to change in built forms is necessary to study building biographies (Herva 2005, p. 220-22I), and therefore, the development of an architectural language.

Moreover, understanding the life histories of buildings also requires a thorough consideration of all the human and non-human components of their environments. With this in mind, the shift from building to architecture as acknowledged here for Minoan Crete

49 On this subject, cf. the very interesting paper by Herva on foundation deposits in Minoan buildings (Herva 2005). 
would also gain by being tackled in the context of the overall change in the Neopalatial period that Knappett recently documented, essentially in the production, distribution and consumption of various goods (Knappett 20II, p. IO6-I22). If invention at the level of the genotype happened at some point at the end of the Protopalatial period, it may have triggered a cascade of innovation that would have had repercussions way beyond the built form. As van der Leeuw puts it: "[...] in every tradition, ultimately ideas, tools and know-how become closely aligned and intertwined into a system in which changes in one domain immediately require changes in many others" (van der Leeuw 2009, p. 245). The concept of 'agent-artefact space' developed by Lane is also very informative in this matter (Lane et al. 2009). It conveys the sense in which a given technology consists of a set of knowledge distributed across various entities - be they agents or artefacts - with various kinds of interconnections (Knappett 20II, p. I56). In such a model, for an innovation to take hold -i.e. for an isolated invention to spread across the network space - there has to be some kind of alteration of that space, which may be physical or conceptual..$^{\circ}$ In this sense, the emergence of configurational thinking and the birth of architecture per se in Minoan Crete certainly played a major role in shaping what is often considered its Golden Age: the Neopalatial period.

50 "The space is dynamic because not only can its structural properties be the very source of invention and creativity, its structures are also subsequently altered by such change. As more artefact types are created, so are new kinds of agents; and these in turn may create new interconnections that in turn spawn yet further problems requiring solutions. As the agent-artefact space changes and grows, more kinds of attributions and exaptations are enabled, leading to more innovation" (Knappett 20II, p. 156). 


\section{Bibliographical references}

\section{Begg, Ian (1975)}

Minoan Storerooms in the Late Bronze Age, University of Toronto (PhD thesis, unpublished).

Begg, Ian (2004a)

“An Archaeology of Palatial Mason's Marks on Crete”, in: Ann Chapin (ed.), Charis. Essays in Honor of S.A. Immerwahr (Hesperia Supplement 33), Princeton, pp. I-25.

\section{Begg, Ian (2004b)}

“An Interpretation of Mason's Marks at Knossos", in: Gerald Cadogan, Eleni Hatzaki, and Andonis Vasilikis (eds.), Knossos: Palace, City, State. Proceedings of the Conference in Herakleion organised by the British School at Athens and the 23rd Ephoreia of Prehistoric and Classical Antiquities of Herakleion, November 2000, for the Centenary of Sir Arthur Evans' Excavations at Knossos, British School at Athens Studies I2, London, pp. 219-223.

Bianco, Giulina (2003)

"Two Different Building Modules of Measurement at Kommos - A Neopalatial Module in Building T and Postpalatial Module in Building P”, in: Karin P. Foster and Robert Laffineur (eds.), Metron. Measuring the Aegean Bronze Age (Aegaeum. Annales d'archéologie égéenne de l'Université de Liège et UT-PASP 24), Liège, Austin, pp. 415-420.

Blier, Suzanne P. (1987)

The Anatomy of Architecture. Ontology and Metaphor in Batammaliba Architectural Expression, Cambridge.

Blier, Suzanne P. (2008)

"Vernacular Architecture", in: Christopher Tilley, Webb Keane, Susanne Kuechler-Fogden, Mike Rowlands, and Patricia Spyer (eds.), Handbook of Material Culture, London, pp. 230-253.

Branigan, Keith (1993)

Dancing with Death: Life and Death in Southern Crete, c. 3000-2000 BC, Amsterdam.

\section{Branigan, Keith (1998)}

"The Nearness of You: Proximity and Distance in Early Minoan Funerary Landscapes", in: Keith Branigan (ed.), Cemetery and Society in the Aegean Bronze Age, Amsterdam, pp. 13-26.

Cherry, John F. (1983)

"Putting the Best Foot Forward", in: Antiquity 57, pp. 52-56.

Cherry, John F. (1986)

"Polities and Palaces: Some Problems in Minoan State Formation", in: Colin Renfrew and John Cherry (eds.), Peer Polity Interaction and Socio-Political Change, Cambridge, pp. I9-45.

Chlouveraki, Stella (2006)

Gypsum in Minoan Architecture: Exploitation, Utilisation and Weathering of a Prestige Stone, University College London (PhD thesis).

Christakis, Kostandinos S. (2008)

The Politics of Storage: Storage and Socio-Political Complexity in Neopalatial Crete, Prehistory Monographs 25, Philadelphia.

Como, Maria Teresa, Kanta, Athanasia, and Marazzi, Massimiliano (2009)

"The Architectural Investigation of the Protopalatial Site of Monastiraki, Crete", in: Martin Bachmann (ed.), Bautechnik im antiken und vorantiken Kleinasien, BYZAS 9, Istanbul, pp. 225-24I. 


\section{Cunningham, Tim (200I)}

"Variations on a Theme: Divergence in Settlement Patterns and Spatial Organization in the Far East of Crete during the Proto- and Neopalatial Periods", in: Keith Branigan (ed.), Urbanism in the Aegean Bronze Age, Sheffield Studies in Aegean Archaeology 4, London, New York, pp. $72-86$.

\section{Cutting, Marion (2003)}

"The Use of Spatial Analysis to Study Prehistoric Settlement Architecture", in: Oxford Journal of Archaeology 22, I, pp. I-2I.

\section{Dabney, Mary K. (1995)}

"The Later Stages of State Formation in Palatial Crete", in: Robert Laffineur and Wolf-Dietrich Niemeier (eds.), Politeia. Society and State in the Aegean Bronze Age. Proceedings of the

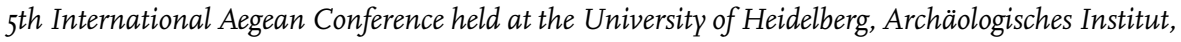
10-13 April 1994 (Aegaeum. Annales d'archéologie égéenne de l'Université de Liège et UTPASP I2), Liège, Austin, pp. 43-47.

\section{Davaras, Costis (1972)}

"The Oval House at Chamaizi Reconsidered", in: Archaiologika Analekta ex Athenon V, 2, pp. $283-288$.

\section{Davaras, Costis (1992)}

"Chamaizi", in: Wilson J. Myers, Eleanor E. Myers, and Gerald Cadogan (eds.), The Aerial Atlas of Ancient Crete, Berkeley, Los Angeles, pp. 78-8I.

Day, Peter M., Wilson, David E., and Kiriatzi, Evangelia (1998)

"Pots, Labels and People: Burying Ethnicity in the Cemetery at Aghia Photia, Siteias", in: Keith Branigan (ed.), Cemetery and Society in the Aegean Bronze Age, Sheffield, pp. I33-I49.

Deshayes, Jean, and Dessenne, André (1959)

Fouilles exécutées à Mallia. Exploration des maisons et quartiers d'habitation (1948-1954), II (Études crétoises XI), Paris.

Devolder, Maud, Déderix, Sylviane, and Fadin, Lionel (forthcoming)

“Recherches aux “Magasins Dessenne’ à Malia”, in: Bulletin de Correspondance Hellénique I37.2.

Dickinson, Oliver T.P.K. (1994)

The Aegean Bronze Age, Cambridge.

Driessen, Jan (1982)

"The Minoan Hall in Domestic Architecture on Crete: To Be in Vogue in Late Minoan IA?", in: Acta Archaeologica Lovaniensia 2I, pp. 27-92.

Driessen, Jan (1989-1990)

"The Proliferation of Minoan Palatial Architectural Style (I) Crete", in: Acta Archaeologica Lovaniensia 28-29, pp. 3-23.

\section{Driessen, Jan (1999)}

"The Dismantling of a Minoan Hall at Palaikastro (Knossian Go Home?)", in: Philip P. Betancourt, Vassos Karagheorgis, Robert Laffineur, and Wolf-Dietrich Niemeier (eds.), Meletemata. Studies in Aegean Archaeology Presented to Malcom H. Wiener as he Enters his 65th Birthday (Aegaeum. Annales d'archéologie égéenne de l'Université de Liège et UT-PASP 20), Liège, Austin, pp. 227-236. 


\section{Driessen, Jan (200I)}

"History and Hierarchy. Preliminary Observations on the Settlement Pattern in Minoan Crete", in: Keith Branigan (ed.), Urbanism in the Aegean Bronze Age (Sheffield Studies in Aegean Archaeology 4), London, New York, pp. 5I-7I.

\section{Driessen, Jan (2004)}

"The Central Court of the Palace at Knossos", in: Gerald Cadogan, Eleni Hatzaki, and Andonis Vasilikis (eds.), Knossos: Palace, City, State. Proceedings of the Conference in Herakleion organised by the British School at Athens and the 23rd Ephoreia of Prehistoric and Classical Antiquities of Herakleion, in November 2000, for the Centenary of Sir Arthur Evans' Excavations at Knossos (British School at Athens Studies 12), London, pp. 75-82.

Driessen, Jan (2005)

"On the Use of Upper Floors in Minoan Neopalatial Architecture", in: Isabelle Bradfer-Burdet, Béatrice Detournay, and Robert Laffineur (eds.), KRHS TEXNITHS. L'artisan crétois. Recueil d'articles en l'honneur de Jean-Claude Poursat, publié à l'occasion des 40 ans de la découverte du Quartier $\mathrm{Mu}$ (Aegaeum. Annales d'archéologie égéenne de l'Université de Liège et UT-PASP 26), Liège, Austin, pp. 83-88.

Driessen, Jan (20I0a)

"Spirit of Place. Minoan Houses as Major Actors", in: Daniel J. Pullen (ed.), Political Economies of the Aegean Bronze Age. Papers from the Langford Conference, Florida State University, Tallahassee, 22-24 February 2007, Oxford, Oakville, pp. 35-65.

\section{Driessen, Jan (20I0b)}

"Malia", in: Eric H. Cline (ed.), The Oxford Handbook of the Bronze Age Aegean (ca. 30001000 BC), Oxford, pp. 556-570.

\section{Driessen, Jan (forthcoming)}

"Beyond the Collective. The Minoan Palace in Action", in: Maria Relaki and Iannis Papadatos (eds.), Studies in Honour of Keith Branigan. Proceedings of the Symposium held at Sheffield University in January 2010.

\section{Driessen, Jan, and Iannis Sakellarakis (1997)}

"The Vathypethro-Complex. Some Observations on its Architectural History and Function", in: Robin Hägg (ed.), The Function of the Minoan Villa. Proceedings of the Eighth International Symposium at the Swedish Institute at Athens, 6-8 June 1992, Stockholm, pp. 63-77.

Fletcher, Roland (1995)

The Limits of Settlement Growth. A Theoretical Outline, Cambridge.

Forde, Daryll (1934)

Habitat, Economy, and Society, London.

Gillespie, Susan D. (2000)

"Beyond Kinship. An Introduction", in: Rosemary A. Joyce and Susan D. Gillespie (eds.), Beyond Kinship: Social and Material Reproduction in House Societies, Philadelphia, pp. I-2I.

Glassie, Henry (2000)

Vernacular Architecture, Bloomington. 


\section{Goodison, Lucy (200I)}

"From Tholos to Throne Room: Perceptions of the Sun in Minoan Ritual", in: Robert Laffineur and Robin Hägg (eds.), Potnia. Deities and Religion in the Aegean Bronze Age (Aegaeum. Annales d'archéologie égéenne de l'Université de Liège et UT-PASP 22), Liège, Austin, pp. 77-89.

Goodison, Lucy (2004)

"From Tholos Tomb to Throne Room: Some Considerations of Dawn Light and Directionality in Minoan Buildings", in: Gerald Cadogan, Eleni Hatzaki, and Andonis Vasilikis (eds.), Knossos: Palace, City, State. Proceedings of the Conference in Herakleion Organised by the British School at Athens and the 23rd Ephoreia of Prehistoric and Classical Antiquities of Herakleion, in November 2000, for the Centenary of Sir Arthur Evans' Excavations at Knossos (British School at Athens Studies I2), London, pp. 339-50.

Graham, James W. (1960)

"The Minoan Unit of Length and Minoan Palace Planning", in: American Journal of Archaeology 64, pp. 335-4I.

Graham, James W. (1977)

"Bathrooms and Lustral Chambers", in: Konrad H. Kinzl (ed.), Greece and the Eastern Mediterranean in Ancient History and Prehistory: Studies Presented to Fritz Schachermeyr on the Occasion of his Eightieth Birthday, Berlin, pp. IIO-I25.

Haggis, Donald C. (1999)

"Staple Finance, Peak Sanctuaries, and Economic Complexity in Late Prepalatial Crete", in: Angelos Chaniotis (ed.), From Minoan Farmers to Roman Traders: Sidelights on the Economy of Ancient Crete, Stuttgart, pp. 53-86.

Hallager, Erik (1990)

“Upper Floors in LM I Houses”, in: Pascal Darcque and René Treuil (eds.), L'habitat égéen préhistorique. Actes de la Table Ronde internationale organisée par le Centre National de la Recherche Scientifique, l'Université de Paris I et l'École Française d'Athènes (Athènes, 23-25juin 1987) (BCH suppl. XIX), Athens, Paris, pp. 28I-292.

\section{Hamilakis, Yiannis (1998)}

"Eating the Dead: Mortuary Feasting and the Politics of Memory in Aegean Bronze Age Societies", in: Keith Branigan (ed.), Cemetery and Society in the Aegean Bronze Age, Amsterdam, pp. II5-32.

Hamilakis, Yiannis (2002)

"Too Many Chiefs?: Factional Competition in Neopalatial Crete", in: Jan Driessen, Ilse Schoep, and Robert Laffineur (eds.), Monuments of Minos. Rethinking the Minoan Palaces (Aegaeum. Annales d'archéologie égéenne de l'Université de Liège et UT-PASP 23), Liège, Austin, pp. I79-I99.

\section{Herva, Vesa-Pekka (2005)}

"The Life of Buildings: Minoan Building Deposits in an Ecological Perspective", in: Oxford Journal of Archaeology 24, 3, pp. 215-227.

\section{Hillier, Bill (1996)}

Space is the Machine. A Configurational Theory of Architecture, Cambridge.

Hillier, Bill, and Hanson, Julienne (1984)

The Social Logic of Space, Cambridge. 
Hitchcock, Louise (1997)

"The Best Laid Plans Go Astray: Modular (Ir)regularities in the 'Residential Quarters' at Phaistos”, in: Philip Betancourt and Robert Laffineur (eds.), TEXNH. Craftsmen, Craftswomen and Craftsmanship in the Aegean Bronze Age (Aegeum. Annales d'archéologie égéenne de l'Université de Liège et UT-PASP I6), Liège, pp. 243-250.

Hitchcock, Louise (2000)

Minoan Architecture. A Contextual Analysis (Studies in Mediterranean Archaeology and Literature I55), Jönsered.

Hitchcock, Louise, and Preziosi, Donald (1997)

“The Knossos Unexplored Mansion and the 'Villa-Annex Complex', in: Robin Hägg (ed.) The Function of the Minoan Villa. Proceedings of the Eighth International Symposium at the Swedish Institute at Athens, 6-8 June 1992, Stockholm, pp. 5I-62.

Ingold, Tim (2000)

The Perception of the Environment. Essays in Livelihood, Dwelling and Skills, London.

Joyce, Rosemary A., and Gillespie, Susan D. (eds.) (2000)

Beyond Kinship: Social and Material Reproduction in House Societies, Philadelphia.

Kanta, Athanasia (1999)

"Monastiraki and Phaistos, Elements of Protopalatial History", in: Philip P. Betancourt, Vassos Karagheorgis, Robert Laffineur, and Wolf-Dietrich Niemeier (eds.), Meletemata. Studies in Aegean Archaeology Presented to Malcom H. Wiener as he Enters his 65th Birthday (Aegaeum. Annales d'archéologie égéenne de l'Université de Liège et UT-PASP 20), Liège, Austin, pp. 387-393.

Kanta, Athanasia (2006)

"Monastiraki, a Minoan Palatial Centre in the Valley of Amari, Crete", in: Anastasia Kanta and Massimiliano Marazzi (eds.), Monastiraki 1. Missione Monastiraki, Campagne 2002/2004, Naples.

Kent, Suzan (1990)

"A Cross-Cultural Study of Segmentation, Architecture, and the Use of Space", in: Suzan Kent (ed.), Domestic Architecture and the Use of Space. An Interdisciplinary Cross Cultural Study, Cambridge, pp. I27-152.

Knappett, Carl (1999)

"Assessing a Polity in Protopalatial Crete: The Malia-Lasithi State", in: American Journal of Archaeology 103, 4, pp. 615-639.

Knappett, Carl (20II)

An Archaeology of Interaction: Network Perspectives on Material Culture and Society, Oxford.

Knappett, Carl, and Tim Cunningham (2012)

Palaikastro Block M. The Proto- and Neopalatial Town (BSA Supplementary Volumes 47), Athens.

Lane, David, van der Leeuw, Sander, Pumain, Denise, and West, Geoffrey (eds.) (2009)

Complexity Perspectives in Innovation and Social Change, New York.

Langohr, Charlotte (2009)

PERIFEREIA. Étude régionale de la Crète aux Minoen Récent II-IIIB (1450-1200 av. J.-C.). 1. La Crète centrale et occidentale (Aegis 2), Louvain-la-Neuve. 
Lembessi, Angeliki (1976)

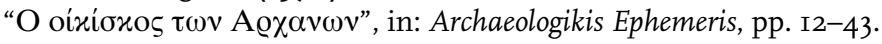

Lenuzza, Valeria (20II)

“'The Whole is a freak': A Reassessment of the Spatial Organization of the Oval House At Chamaizi, Siteia", in: Glowacki, Kevin T. and Vogeikoff-Brogan, Natalia (eds.), Stega. The Archaeology of Houses and Households in Ancient Crete (Hesperia Supplement 44), Princeton, pp. 59-70.

Letesson, Quentin (2009)

Du phénotype au génotype: analyse de la syntaxe spatiale en architecture minoenne (MMIIIB$L M I B$ ) (Aegis 2), Louvain-la-Neuve.

Letesson, Quentin, and Vansteenhuyse, Klaas (2006)

“Towards an Archaeology of Perception. 'Looking' at the Minoan Palaces”, in: Journal of Mediterranean Archaeology I9, I, pp. 9I-II9.

Letesson, Quentin, and Driessen, Jan (2008)

“From 'Party' to 'Ritual' to 'Ruin': The Spatial Context of Feasting”, in: Louise Hitchcock, Robert Laffineur, and Janice Crowley (eds.), DAIS. The Aegean Feast (Aegaeum 29), Liège, Austin, pp. 207-215.

MacDonald, Colin F. (2002)

"The Neopalatial Palace of Knossos", in: Jan Driessen, Ilse Schoep, and Robert Laffineur (eds.), Monuments of Minos. Rethinking the Minoan Palaces (Aegaeum. Annales d'archéologie égéenne de l'Université de Liège et UT-PASP 23), Liège, Austin, pp. 35-55.

MacDonald, Colin F., Hallager, Erik, and Niemeier, Wolf-Dietrich (eds.) (2009)

The Minoans in the Central, Eastern and Northern Aegean - New Evidence (Monographs of the Danish Institute at Athens 8), Athens.

MacGillivray, Joseph A., and Driessen Jan (1990)

"Minoan Settlement at Palaikastro", in: Pascal Darcque and René Treuil (eds.), L'habitat égéen préhistorique. Actes de la Table Ronde internationale organisée par le Centre National de la Recherche Scientifique, l'Université de Paris I et l'École Française d'Athènes, Athènes, 23-25 juin 1987, (Bulletin de Correspondance Hellénique supplément XIX), Athens, Paris, pp. 395-4I2.

MacGillivray, Joseph A., and Sackett, Hugh L. (2010)

"Palaikastro", in: Eric H. Cline (ed.), The Oxford Handbook of the Bronze Age Aegean (ca. 3000-1000 BC), Oxford, pp. 57I-58I.

McEnroe, John (1990)

"The Significance of Local Styles in Minoan Vernacular Architecture", in: Pascal Darcque and René Treuil (eds.), L'habitat égéen préhistorique. Actes de la Table Ronde internationale organisée par le Centre National de la Recherche Scientifique, l'Université de Paris I et l'École Française d'Athènes (Athènes, 23-25 juin 1987) (BCH suppl. XIX), Athens, Paris, pp. I95-202.

McEnroe, John (2010)

Architecture of Minoan Crete. Constructing Identity in the Aegean Bronze Age, Austin.

Mirié, Sieglinde (1979)

Das Thronraumareal des Palastes von Knossos: Versuch einer Neuinterpretation seiner Entstehung und seiner Funktion (Saarbrücker Beiträge zur Altertumskunde 26), Bonn.

Müller, Béatrice (200I)

“'Maquettes architecturales' de l'Antiquité. Regards croisés (Proche-Orient, Égypte, Chypre, bassin égéen et Grèce, du Néolithique à l'époque hellénistique)", Actes du Colloque de Strasbourg, 3-5 décembre 1998, Paris. 
Murphy, Joanne (1998)

"Ideologies, Rites and Rituals: A View of Prepalatial Minoan Tholoi", in: Keith Branigan (ed.), Cemetery and Society in the Aegean Bronze Age, Amsterdam, pp. 27-40.

Murphy, Joanne (2010)

"Political Economies in Ritual: A Comparative Study of the Rise of the State in Preand Protopalatial Knossos and Phaistos", in: Daniel J. Pullen (ed.), Political Economies of the Aegean Bronze Age. Papers from the Langford Conference, Florida State University, Tallahassee, 22-24 February 2007, Oxford, Oakville, pp. II2-I26.

Niemeier, Wolf-Dietrich (1987)

"On the Function of the 'Throne Room' in the Palace at Knossos", in: Robin Hägg and Nanno Marinatos (eds.), The Function of the Minoan Palaces. Proceedings of the Fourth International Symposium at the Swedish Institute in Athens, 10-16 June, 1984, 4, XXXV, Stockholm, pp. $163-168$.

Ostwald, Michael (20II)

"The Mathematics of Spatial Configuration: Revisiting, Revising and Critiquing Justified Plan Graph Theory", in: Nexus Network Journal I3.2, pp. 445-470.

Palyvou, Clairy (1987)

"Circulatory Patterns in Minoan Architecture" in: Robin Hägg and Nanno Marinatos (eds.), The Function of the Minoan Palaces. Proceedings of the Fourth International Symposium at the Swedish Institute in Athens, 10-16 June, 1984, 4, XXXV, Stockholm, pp. 195-203.

Palyvou, Clairy (2002)

"Central Courts: The Supremacy of the Void", in: Jan Driessen, Ilse Schoep, and Robert Laffineur (eds.), Monuments of Minos. Rethinking the Minoan Palaces (Aegaeum. Annales d'archéologie égéenne de l'Université de Liège et UT-PASP 23), Liège, Austin, pp. 167-178.

Palyvou, Clairy (2005)

Akrotiri Thera. An Architecture of Affluence 3,500 Years Old, Philadelphia.

Preucel, Robert W. (2000)

"Making Pueblo Communities: Architectural Discourse at Kotyiti, New Mexico", in: Marcello A. Canuto and Jason Yaeger (eds.), The Archaeology of Communities. A New World Perspective, London, New York, pp. 58-77.

Poblome, Jeroen, and Christine Dumon (1987-1988)

"A Minoan Building Program? Some Comments on the Unexplored Mansion at Knossos", in: Acta Archaeologica Lovaniensia 26-27, pp. 69-79.

Poursat, Jean-Claude (1978)

Fouilles exécutées à Mallia. Le Quartier Mu I (Études Crétoises XXIII), Paris.

Poursat, Jean-Claude (1987)

“Town and Palace at Malia in the Protopalatial Period", in: Robin Hägg and Nanno Marinatos (eds.), The Function of the Minoan Palaces. Proceedings of the Fourth International Symposium at the Swedish Institute in Athens, 10-16 June, 1984, 4, XXXV), Stockholm, pp. 75-76.

Poursat, Jean-Claude (1992)

Guide de Malia au temps des premiers palais. Le Quartier Mu (École française d'Athènes. Sites et monuments VIII), Paris.

Poursat, Jean-Claude (1996)

Fouilles exécutées à Malia. Le Quartier Mu III. Artisans minoens: les maisons-ateliers du quartier Mu (Études Crétoises XXXII), Paris. 
Poursat, Jean-Claude, and Knappett, Carl (2005)

Fouilles exécutées à Malia. Le Quartier Mu IV. La poterie du Minoen Moyen II: production et utilisation (Études Crétoises XXXIII), Paris.

\section{Preziosi, Donald (1979)}

The Semiotics of the Built Environment: An Introduction to Architectonic Analyses, Bloomington, London.

\section{Preziosi, Donald (1983)}

Minoan Architectural Design. Formation and Signification (Approaches to Semiotics 63), Berlin, New York.

\section{Preziosi, Donald (2003)}

"What Does a Module Mean?", in: Karin P. Foster and Robert Laffineur (eds.), Metron. Measuring the Aegean Bronze Age (Aegaeum. Annales d'archéologie égéenne de l'Université de Liège et UT-PASP 24), Liège, Austin, pp. 233-237.

\section{Pullen, Daniel J. (2010)}

"Introduction: Political Economies of the Aegean Bronze Age", in: Daniel J. Pullen (ed.), Political Economies of the Aegean Bronze Age, Oxford, Oakville, pp. I-IO.

\section{Roux, Valentine (2010)}

“Technologie et cognition", in: L'archéologie en mouvement: hommes, objets et temporalités (CNRS/INSHS), Paris 23-25 June 2010, http://webcast.in2p3.fr/20Io/archeomouv/index. php?video=roux.ram (29 February 2010).

\section{Sanders, Donald H. (1984)}

Behavior and the Built Environment: An Interpretive Model for the Analysis of the Architecture in an Archaeological Context and Its Testing on Material from the Aegean Bronze Age Site of Mrrtos, Crete, (Ph.D. thesis, unpublished).

\section{Sanders, Donald H. (1988)}

"Architecture, the Neglected Artifact", in: Elizabeth B. French and Diane E.H. Wardle (eds.), Problems in Greek Prehistory. Papers presented at the Centenary Conference of the British School of Archaeology at Athens, Manchester April 1986, Bristol, pp. 489-499.

\section{Sanders, Donald H. (1990)}

"Behavioral Conventions and Archaeology: Methods for the Analysis of Ancient Architecture", in: Suzan Kent (ed.), Domestic Architecture and the Use of Space. An Interdisciplinary Cross-Cultural Study (New Directions in Archaeology), Cambridge, pp. 43-72.

\section{Schoep, Ilse (1994)}

"Home Sweet Home. Some Comments on the So-called House Models from the Prehellenic Aegean", in: Opuscula Atheniensa 20, pp. I89-210.

Schoep, Ilse (1999)

"Tablets and Territories? Reconstructing Late Minoan IB Political Geography through Undeciphered Documents", in: American Journal of Archaeology I03, pp. 20I-22I.

Schoep, Ilse (2002)

"Social and Political Organisation on Crete in the Proto-Palatial Period: The Case of Malia in MMII", in: Journal of Mediterranean Archaeology I5, 2, pp. IO2-25. 
Schoep, Ilse (2004)

"Assessing the Role of Architecture in Conspicuous Consumption in the Middle Minoan I-II Periods", in: Oxford Journal of Archaeology 23, 3, pp. 243-269.

Schoep, Ilse (2006)

"Looking Beyond the First Palaces: Elites and the Agency of Power in EMIII-MMII Crete", in: American Journal of Archaeology IIO, pp. 37-64.

Schoep, Ilse (2010a)

"Making Elites: Political Economy and Elite Culture(s) in Middle Minoan Crete", in: Daniel J. Pullen (ed.), Political Economies of the Aegean Bronze Age. Papers from the Langford Conference, Florida State University, Tallahassee, 22-24 February 2007, Oxford, Oakville, pp. 66-85.

Schoep, Ilse (20Iob)

"Middle Bronze Age. Crete", in: Eric H. Cline (ed.), The Oxford Handbook of the Bronze Age Aegean (ca. 3000-1000 BC), Oxford, pp. II3-125.

Shaw, Joseph W. (1973)

"The Orientation of the Minoan Palaces", in: Antichità cretesi. Studi in onore di Doro Levi. Cronache di archeologia I2, pp. 47-59.

Shaw, Joseph W. (2009)

Minoan Architecture: Materials and Techniques (Studi di archaeologia cretese VII), Padua.

Shaw, Joseph W. (20II)

"Tracing the Ancestry of the Minoan Hall System", in: Annual of the British School at Athens I06, pp. I4I-I65.

Shaw, Joseph W., and Shaw, Maria C. (eds.) (1996)

Kommos I. The Kommos Region and Houses of the Minoan Town. Part 2. The Minoan Hilltop and Hillside Houses, Princeton.

Schmid, Martin (1985)

“Esquisse du tracé d'un ensemble architectural de l'époque minoenne: Malia, le Quartier $\mathrm{Mu}$ ", in: Le dessin d'architecture dans les sociétés antiques. Actes du Colloque de Strasbourg 26-28 janvier 1984 (Université des sciences humaines de Strasbourg. Travaux du centre de recherche sur le Proche Orient et la Grèce antiques 8), Leiden, pp. 63-73.

\section{Todaro, Simona (2012)}

"Craft Production and Social Practices at Prepalatial Phaistos: The Background to the First 'Palace'”, in: Ilse Schoep, Peter Tomkins, and Jan Driessen (eds.), Back to the Beginning. Reassessing Social and Political Complexity on Crete during the Early and Middle Bronze Age, Oxford, Oakville, pp. I95-235.

Tomkins, Peter, and Schoep, Ilse (2010)

"Early Bronze Age. Crete", in: Eric H. Cline (ed.), The Oxford Handbook of the Bronze Age Aegean (ca. 3000-1000 BC), Oxford, pp. 66-82.

\section{Tomkins, Peter (2007)}

"Communality and Competition: The Social Life of Food and Containers at Aceramic and Early Neolithic Knossos, Crete", in: Christopher Mee and Josette Renard (eds.), Cooking Up the Past: Food and Culinary Practices in the Neolithic and Bronze Age Aegean, Oxford, pp. I74-I99. 
Tomkins, Peter (2012)

"Behind the Horizon: Reconsidering the Genesis and Function of the 'First Palace' at Knossos (Final Neolithic IV-Middle Minoan IB)”, in: Ilse Schoep, Peter Tomkins, and Jan Driessen (eds.), Back to the Beginning. Reassessing Social and Political Complexity on Crete during the Early and Middle Bronze Age, Oxford, Oakville, pp. 32-80.

\section{Tomkins, Peter (forthcoming)}

"Landscapes of Identity, Ritual and Memory: Reconsidering the Use of Caves on Crete during the Neolithic and Early Bronze Age", in: Moyes Holley (ed.), Journeys into the Dark Zone, Colorado.

Treuil, René (1996)

“De la cigale à la fourmi: les origines des magasins à vivres dans le monde égéen", in: Topoi 6, pp. 7I-83.

Treuil, René (1999)

“Les 'Maisons Dessenne' à Malia”, in: Philip P. Betancourt, Vassos Karagheorgis, Robert Laffineur, and Wolf-Dietrich Niemeier (eds.), Meletemata. Studies in Aegean Archaeology Presented to Malcom H. Wiener as he Enters his 65th Birthday (Aegaeum. Annales d'archéologie égéenne de l'Université de Liège et UT-PASP 20) Liège, Austin, pp. 84I-845.

\section{Tsipopoulou, Metaxia (1988)}

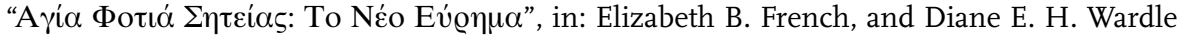
(eds.), Problems in Greek Prehistory. Papers Presented at the Centenary Conference of the British School of Archaeology at Athens, Manchester April 1986, Bristol, pp. 3I-47.

Tsipopoulou, Metaxia (1992)

"Ayia Photia", in: Wilson J. Myers, Eleanor E. Myers, and Gerald Cadogan (eds.), The Aerial Atlas of Ancient Crete, Berkeley, Los Angeles: pp. 66-69.

Tuner, Alan (200I)

"Depthmap. A Program to Perform Visibility Graph Analysis", in: John Peponis, Jean Wineman, and Sonit Bafna (eds.), Proceedings of the 3rd International Symposium on Space Syntax, Atlanta, 3I.I-3I.9.

Turner, Alan (2004)

Depthmap 4 - A Researcher's Handbook, London. (http://discovery.ucl.ac.uk/265I/)

Van der Leeuw, Sander E. (2008)

"Agency, Networks, Past and Future", in: Carl Knappett and Lambros Malafouris (eds.), Material Agency. Towards a Non-Anthropocentric Approach, New York, pp. 217-247.

Van Effenterre, Henry (1980)

Le palais de Mallia et la cité minoenne. Étude de synthèse, Rome.

Warren, Peter (1972)

Myrtos. An Early Bronze Age Settlement in Crete (Annual of the British School at Athens Supplementary Volume 7), London.

Whitelaw, Todd M. (1983)

"The Settlement at Fournou Korifi, Myrtos and Aspects of Early Minoan Social Organization", in: Olga Krzyszkowska and Lucy Nixon (eds.), Minoan Society. Proceedings of the Cambridge Colloquium 1981, Bristol, pp. 323-345. 